\title{
The influence of boreal winter extratropical North Pacific Oscillation on Australian spring rainfall
}

\author{
Linye Song ${ }^{1,2} \cdot$ Yun $\mathrm{Li}^{3} \cdot$ Wansuo Duan ${ }^{2}$
}

Received: 10 June 2015 / Accepted: 24 October 2015 / Published online: 5 November 2015

(C) The Author(s) 2015. This article is published with open access at Springerlink.com

\begin{abstract}
The North Pacific Oscillation (NPO) is a key atmospheric intrinsic mode. This study concerns mechanisms that the NPO influences Southern Hemisphere climate anomalies after several months. It is found that the boreal wintertime NPO has a significant negative connection with austral spring rainfall anomalies in Australia, particularly in the Northern Territory, Queensland, New South Wales and Victoria. A positive NPO phase tends to be followed by dry conditions, while a negative phase by wet conditions in austral spring over much of northern and eastern Australia. The physical mechanism by which the boreal winter NPO affects Australian rainfall arises from the NPO seasonal footprinting mechanism that generates significant tropical central and eastern Pacific sea surface temperature (SST) warming anomalies during austral spring. Then, the positive NPO-related SST warming anomalies over the tropical central-eastern Pacific further induce a weakened Walker circulation, with its western subsiding branch over Australia, suppressing convection and thereby reducing rainfall. Furthermore, the NPO plays an important role in contributing to the significant long-term trends of the Northern Territory and Queensland rainfalls. The decreasing amplitude of the NPO contributes much of the observed rainfall wetting trends in the Northern Territory $(\sim 50 \%)$ and Queensland ( 60\%) regions during 1951-2010. Noted
\end{abstract}

Wansuo Duan

duanws@lasg.iap.ac.cn

1 Institute of Urban Meteorology, China Meteorological Administration, Beijing, China

2 LASG, Institute of Atmospheric Physics, Chinese Academy of Sciences, Beijing 100029, China

3 Business Intelligence and Data Analytics, Western Power, Perth, WA 6000, Australia that caution is recommended regarding the Australian spring rainfall trend results obtained in this study as the austral spring rainfall trends may be sensitive to the choice of the selected time period.

Keywords North Pacific Oscillation · Austral spring rainfall $\cdot$ Seasonal footprinting mechanism $\cdot$ Walker circulation

\section{Introduction}

Australia is a major agricultural producer and exporter in the world. Agriculture and its closely related sectors earn $\$ 155$ billion-a-year for a $12 \%$ share of Australia's total gross domestic product (GDP) (http://www.nff.org.au/ farm-facts.html). On one hand, Australia is one of the driest inhabited continents in the word, with a climate characterizing as highly variable and experiencing seasonal-scale droughts with large interdecadal variability (Gallant et al. 2007). Hence, one of the major issues facing agriculture in Australia is drought, which may result in challenges to water availability and quality for agriculture leading to serious loss of agricultural production. For example, eastern Australia experienced a severe drought event in 2002-2003 that resulted in a $\sim 25 \%$ drop of Australia's gross farm product (Lu and Hedley 2004). On the other hand, severe droughts in Australian history were often associated with the reduction of austral spring (September-November, SON) rainfall (BOM 2006). For example, despite slightly above normal summer/autumn rainfall, in 2006, the latewinter to mid-spring rainfalls had decreased, resulting in the 2006 annual rainfall being 40-60\% below normal over most of Australia south of the Tropic of Capricorn. In contrast, the 2010 wettest spring recorded in eastern Australian 


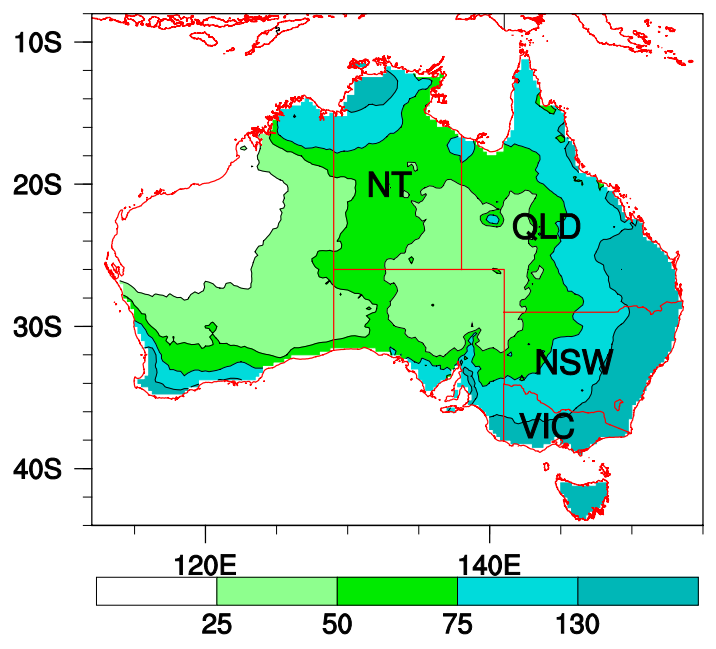

Fig. 1 Australian spring (austral spring) rainfall average during 1951-2010 (unit: mm). The Northern Territory (NT), and the states of Queensland $(Q L D)$, New South Wales $(N S W)$ and Victoria (VIC) are shown

regions (Queensland, New South Wales and Victoria) since 1993 also saw the ease of long term drought conditions during 1995-2009 in eastern Australia. Therefore, understanding and building a forecasting skill of Australian spring rainfall is important for agriculture, economic growth and people's daily life in Australia.

Figure 1 shows the climatology of spring rainfall in Australia for the period 1951-2010 using the rainfall data from the Australian Water Availability Project. Maximum rainfall occurred along the southeastern and eastern coast, as well as the northern and southwestern coast, decreasing far inland. Previous studies demonstrated that Australian spring rainfall is influenced by many factors, such as the El Niño-Southern Oscillation (ENSO) (e.g., McBride and Nicholls 1983; Ropelewski and Halpert 1987; Nicholls et al. 1996; Chiew et al. 1998; Taschetto and England 2009), the Indian Ocean dipole (e.g., Saji et al. 1999; Ashok et al. 2003; Ummenhofer et al. 2011), and the Antarctic Oscillation or southern annular mode (e.g., Gong and Wang 1999; Thompson and Wallace 2000; Marshall 2003; Hendon et al. 2007). For example, studies find that Australian rainfall tends to be below average during El Niño events and above average during La Niña events, especially across the eastern two-thirds of the Australian continent during austral spring (e.g., Allan 1988; Wang and Hendon 2007). Anomalous Walker circulation plays an important role in relaying the influence of the ENSO on Australian rainfall (Wang and Hendon 2007). The influence of these modes on Australian rainfall varies regionally and seasonally (Risbey et al. 2009).

The North Pacific Oscillation (NPO) has recently emerged in the literature as a key atmospheric mode in extratropical Northern Hemisphere climate variability. It is the second empirical orthogonal function (EOF) mode of North Pacific sea level pressure (SLP) anomalies. The NPO consists of a meridional dipole in SLP anomalies over the North Pacific, with centers over Alaska and near Hawaii (e.g., Walker and Bliss 1932; Rogers 1981; Vimont et al. 2003a; Linkin and Nigam 2008). The NPO significantly influences downstream weather and climate conditions over North America during wintertime (e.g., Rogers 1981; Linkin and Nigam 2008). For example, the NPO mode is associated with large regional variations in air temperature and precipitation, promoting increased cold outbreaks in the central and eastern United States, and drier conditions along northwestern North America. Studies also found that the NPO affects upstream climate anomalies, such as the East Asian climate variability (e.g., Liu et al. 2010; Choi et al. 2011; Zheng et al. 2012). A significant relationship between temperature and precipitation in Changchun of China and the NPO exists in the frequency band up to 7 months, with increased temperature and decreased rainfall when the NPO is positive (Liu et al. 2010). However, it is still unclear whether the NPO influences climate anomalies in the Southern Hemisphere.

Previous studies demonstrate that boreal wintertime NPO (November-March, NDJFM) is a potential stochastic extratropical atmospheric precursor signal of ENSO events during the following winter through the seasonal footprinting mechanism (SFM; e.g., Vimont et al. 2001, 2003a, b; Anderson 2003, 2004, 2007; Anderson and Maloney 2006; Zhang et al. 2009; Alexander et al. 2010; Chen et al. 2013). The SFM has been verified both in observations (Vimont et al. 2003b; Anderson 2003, 2004, 2007; Chen et al. 2013) and numerical models (e.g., Vimont et al. 2001, 2003a; Anderson and Maloney 2006; Zhang et al. 2009; Alexander et al. 2010). Because the NPO is linked to the tropical Pacific SST variability, and the tropical Pacific SST anomaly is an important contributor to Australian rainfall variations, it can be speculated that the NPO may exert its influence on Australian rainfall via SST anomalies over the tropical central-eastern Pacific. If such a connection exists, then the NPO can be used to predict Australian rainfall anomalies in advance.

In this study, we demonstrate that the boreal winter (November-March average) NPO can exert a significant influence on Australian rainfall anomalies in the following austral spring. The remainder of the paper is organized as follows. Section 2 describes the data sets and methods used in this study. The interannual connection between Australian spring rainfall and the NPO is investigated in Sect. 3. In Sect. 4, the physical mechanism by which the NPO influences the Australian rainfall is examined. The contribution of NPO to the long-term trend of Australian spring rainfall is analyzed in Sect. 5. Finally, Sect. 6 is a summary. 


\section{Data and methods}

We employ monthly rainfall dataset from the Australian Water Availability Project (AWAP) on a $0.25^{\circ} \times 0.25^{\circ}$ horizontal grid (Jones et al. 2009; Raupach et al. 2009). In addition, the state-averaged rainfall time series in austral spring (September-November, SON) in four states of the Northern Territory, Queensland, New South Wales and Victoria (see Fig. 1) are downloaded from the website of Australian Bureau of Meteorology (http://www.bom.gov. au/cgi-bin/climate/change/timeseries.cgi?graph=rain\&area $=$ nt\&season=0911\&ave_yr=0).

Monthly atmospheric fields used in this study are obtained from the National Centers for Environment Prediction-National Center for Atmospheric Research (NCEPNCAR) Reanalysis Project (Kalnay et al. 1996; Kistler et al. 2001; ftp://ftp.cdc.noaa.gov/Datasets/), including horizontal winds, vertical velocity, and surface precipitable water content. The horizontal winds and vertical velocity are available on $2.5^{\circ} \times 2.5^{\circ}$ horizontal grid and 17 vertical pressure levels ranging from 1000 to $10 \mathrm{hPa}$ from 1948 to the present. Surface precipitable water content is also available on $2.5^{\circ} \times 2.5^{\circ}$ horizontal grid from 1948 to present. The velocity potential is calculated from zonal and meridional winds.

In addition, monthly mean SST data used in this study are extracted from the National Oceanic and Atmospheric Administration (NOAA) Extended Reconstructed SST version 3b (ERSST v3b) (Smith et al. 2008; http://www.esrl. noaa.gov/psd/data/gridded/data.noaa.ersst.html). This SST data set has a horizontal resolution of $2^{\circ} \times 2^{\circ}$ and is available from 1854 to the present. In this study, the Niño3.4 index is used to characterize the ENSO variability, defined as the area averaged SST anomalies over the region of $5^{\circ} \mathrm{S}-$ $5^{\circ} \mathrm{N}, 170^{\circ} \mathrm{W}-120^{\circ} \mathrm{W}$.

The monthly mean SLP data set used in this study is provided by the UK Met Office Hadley Centre (HadSLP2) (Allan and Ansell 2006; http://www.metoffice.gov.uk/ hadobs/hadslp2). This data set has a $5^{\circ} \times 5^{\circ}$ horizontal resolution and is available from 1850 to the present.

To reveal the dominant coupling mode between the North Pacific SLP anomalies and the Australian rainfall anomalies, the singular value decomposition (SVD) technique is used in this study. It has been demonstrated that the SVD analysis can be used to determine two coupled sets of orthogonal singular vectors, as well as the expansion coefficient correlations from the covariance matrix of two geophysical fields (Bretherton et al. 1992; Wallace et al. 1992; Cherry 1996). In addition, partial correlation (Ashok et al. 2003; Feng et al. 2010) and partial regression (Lin and Li 2012) methods are employed to estimate the connection between two variables after removing the effect of another variable. We also use conventional correlation and regression analysis. The significance of correlation and regression coefficients is estimated using a two-tailed Student's $t$ test. The time period analyzed in this study is 1951-2010. The climatological monthly mean based on the period 1951-2010 for each calendar month was removed to obtain the monthly mean anomalies.

\section{Connection between Australian spring rainfall and the NPO}

Figure 2 shows the SVD mode of boreal wintertime $(\mathrm{ND}(-1) \operatorname{JFM}(0))$ SLP anomalies over the North Pacific $\left(0^{\circ}-75^{\circ} \mathrm{N}, 110^{\circ} \mathrm{E}-100^{\circ} \mathrm{W}\right)$ and austral spring $(\mathrm{SON}(0))$ rainfall anomalies over the whole of Australia. Here and for the remainder of this study, the time notations $(0)$ and $(-1)$ refer to the year during and before the rainfall year, respectively. The first SVD mode accounts for $82.2 \%$ of the total covariance and the expansion coefficients of SLP and rainfall are highly correlated, yielding a correlation coefficient 0.51 (Fig. 2c). The SLP pattern in Fig. 2a is characterized by a north-south dipole pattern with a significant positive center over the mid-high latitude North Pacific near Alaska, and a significant negative center over the subtropical North Pacific near Hawaii. This SLP anomalous pattern resembles a typical NPO pattern, as documented by previous studies (e.g., Walker and Bliss 1932; Rogers 1981; Linkin and Nigam 2008; Furtado et al. 2012). The rainfall pattern in Fig. $2 b$ is marked by a mono-sign anomaly in Australia, with significant negative rainfall anomalies over most parts of eastern and northern Australia. These results strongly indicate that the rainfall over eastern and northern Australian continent during austral spring tends to be less than normal when the preceding boreal winter NPO is in its positive phase, while more than normal in its negative phase. It should be mentioned that we define the anomalous SLP pattern in Fig. 2a as a positive NPO phase.

According to the results of SVD, we define an SLP index to quantitatively depict the north-south dipole pattern and use it as the NPO index. In this study, the NPO index is defined as the difference of area-averaged SLP anomalies between the North Pole $\left(45^{\circ}-70^{\circ} \mathrm{N}, 175^{\circ}-125^{\circ} \mathrm{W}\right)$ and South Pole $\left(10^{\circ}-25^{\circ} \mathrm{N}, 175^{\circ} \mathrm{E}-145^{\circ} \mathrm{W}\right)$ (see Fig. 2a). The correlation coefficient between the NPO index (black line in Fig. 2c) and the expansion coefficient time series of SVD SLP (blue line in Fig. 2c) is 0.96. Furthermore, the correlation coefficient between the NPO index defined in this study and the NPO index used in previous studies are significant at the $95 \%$ confidence level (Table 1). Specifically, the correlation coefficients of the NPO index calculated in this study with that defined by Furtado et al. (2012), Park et al. (2013) and Anderson (2003) are 0.93, 0.53 and 0.40, respectively. Furtado et al. (2012) defined NPO index as 


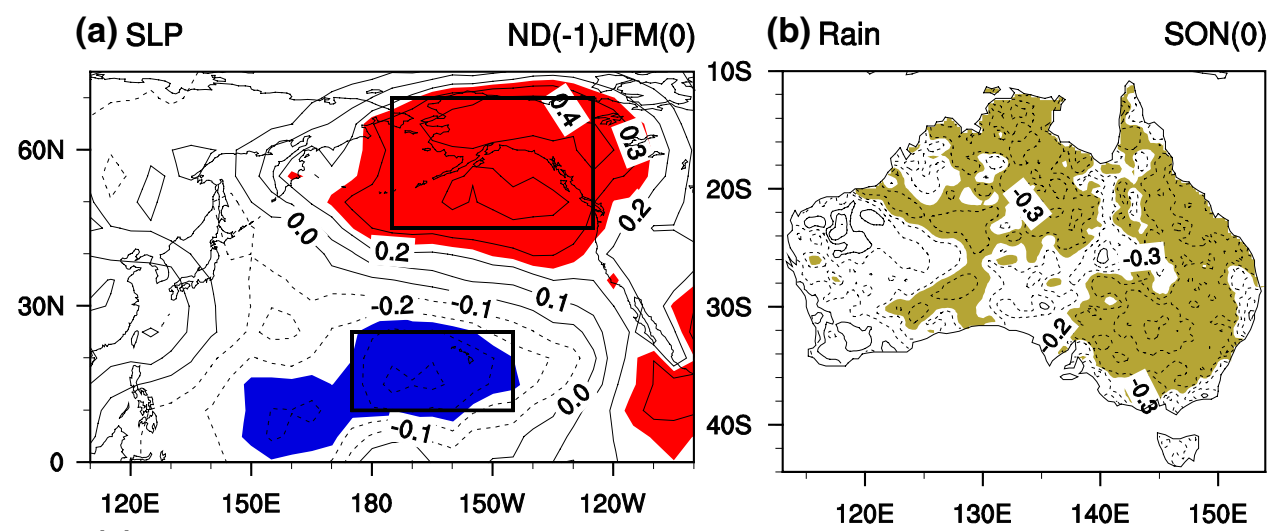

(c)

First Mode (82.2\%)

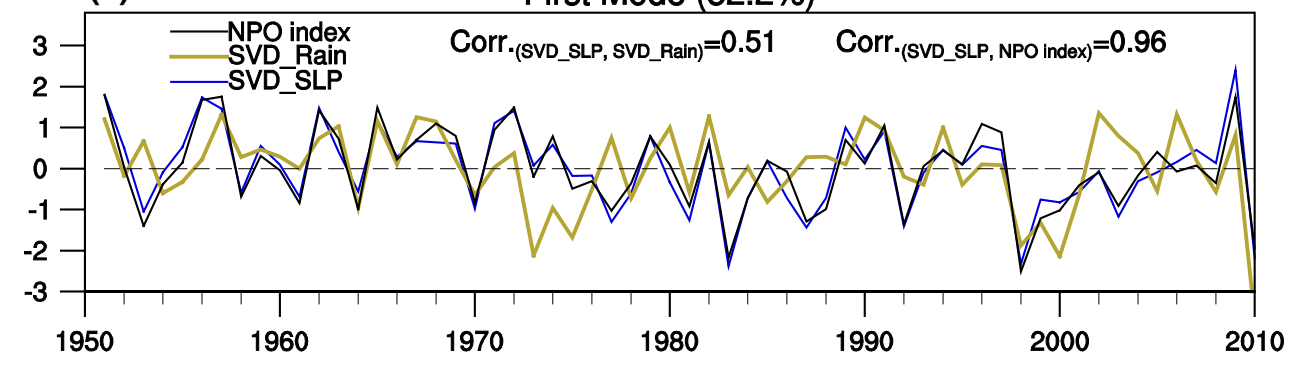

Fig. 2 The first leading singular value decomposition (SVD) heterogeneous modes (contours; shading denotes the $95 \%$ confidence level) of a the preceding boreal winter $(\mathrm{ND}(-1) \mathrm{JFM}(0))$ sea level pressure (SLP) anomalies over the North Pacific $\left(0^{\circ}-75^{\circ} \mathrm{N}\right.$, $\left.110^{\circ} \mathrm{E}-100^{\circ} \mathrm{W}\right)$, b austral spring ( $\left.\mathrm{SON}(0)\right)$ rainfall anomalies in Australia and $\mathbf{c}$ the normalized time series of the first leading SVD mode during 1951-2010. Also shown in $\mathbf{c}$ is the normalized time series of the NPO index. The NPO index is defined as the difference of the area-averaged SLP anomalies between the regions of $\left(45^{\circ}-70^{\circ} \mathrm{N}\right.$, $\left.175^{\circ}-125^{\circ} \mathrm{W}\right)$ and $\left(10^{\circ}-25^{\circ} \mathrm{N}, 175^{\circ} \mathrm{E}-145^{\circ} \mathrm{W}\right)$. The regions used to define the NPO index are shown in a
Table 1 Correlation coefficients of the North Pacific Oscillation (NPO) index defined in this study with other NPO indices defined in previous studies using different methods

\begin{tabular}{llll}
\hline Correlated indices & Corr. & Definition & Source \\
\hline $\mathrm{R}_{(\mathrm{NPO} \text { index, NPO NP-SP) }}$ & 0.93 & {$[\mathrm{SLPa}]_{\mathrm{NP}}-[\mathrm{SLPa}]_{\mathrm{SP}}$} & Furtado et al. (2012) \\
& & SP:55-72.5N,180-140W; NP:15-27.5N,175E-147.5W & \\
$\mathrm{R}_{(\mathrm{NPO} \text { index, NPO EOF) }}$ & 0.53 & EOF-2 of North Pacific SLPa $(0-70 \mathrm{~N}, 110 \mathrm{E}-80 \mathrm{~W})$ & Park et al. (2013) \\
$\mathrm{R}_{(\mathrm{NPO} \text { index, NPO SP) }}$ & 0.40 & {$[\mathrm{SLPa}]_{\mathrm{SP}}$} & Anderson (2003) \\
& & SP:10-25N,175W-140W & \\
\hline
\end{tabular}

The square brackets represent the area-averaged sea level pressure (SLP) anomalies over each of the regions. All correlations were significant at the $95 \%$ confidence level. NP (SP) represents northern (southern) lobe of NPO
SLP difference between two different regions, similar to the method used in this study. Park et al. (2013) defined NPO index via an empirical orthogonal function (EOF) method. As the SLP anomalies on the southern lobe of the NPO circulation have been identified as a critical region for impacting the tropical Pacific, many previous studies defined the NPO index as SLP anomalies over the subtropical North Pacific (i.e. the southern lobe of the NPO) to investigate the SFM (Anderson 2003, 2007; Zhang et al. 2009; Alexander et al. 2010; Deser et al. 2012).

To further confirm the significant connection between the preceding boreal winter NPO related circulation anomalies and the following austral spring rainfall anomalies,
Fig. 3a presents the correlation map between the boreal winter NPO index and austral spring rainfall anomalies in Australia. Large areas of significant negative correlation are observed over most parts of Australia (Fig. 3a). To verify whether the correlation between the boreal winter NPO and austral spring rainfall is influenced by the preceding ENSO, a partial correlation approach is applied to remove the boreal winter ENSO signal. It shows that the NPOrainfall relationship remains significant after removing the boreal wintertime ENSO influence (Fig. 3b). In addition, their interannual connection is still robust after removing the long-term trend (Fig. 3c). The contribution of the boreal winter NPO to the long-term trend of austral spring 
(a)

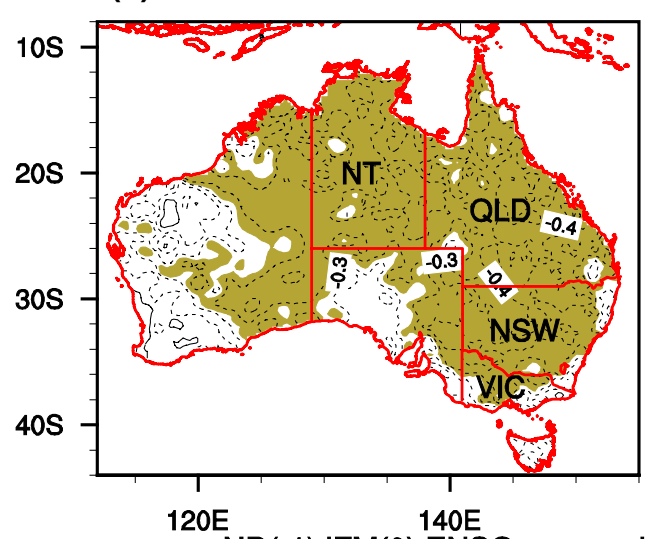

(b)

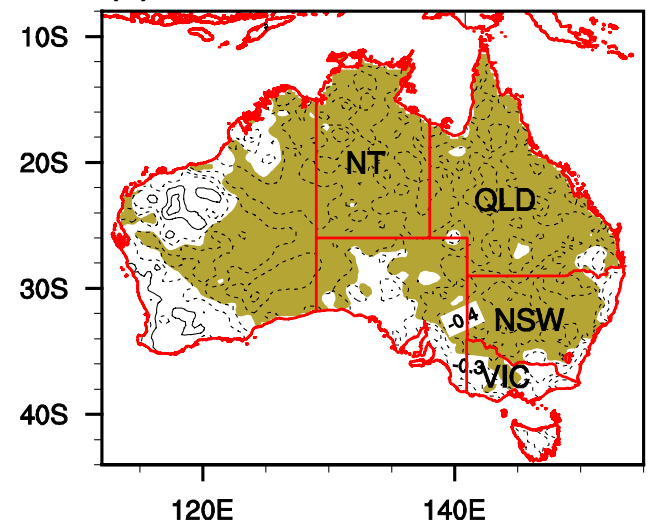

(c)

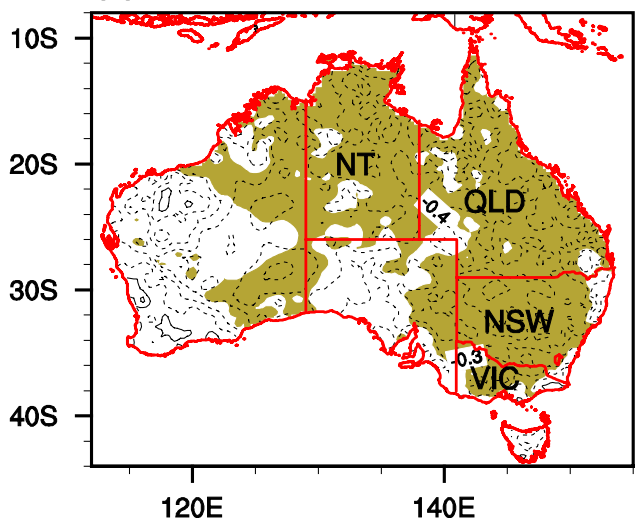

Fig. 3 a Correlation of the boreal wintertime NPO index defined in this study according to the results of SVD with Australian rainfall in austral spring during 1951-2010, based on original data; $\mathbf{b}$ as a with boreal winter Nino3.4 index linearly removed from the NPO index (d) Furtado et al. (2012)

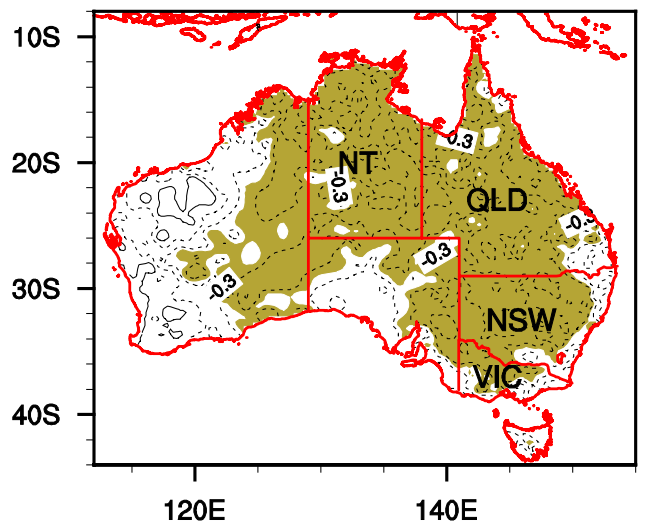

(e)

Furtado et al. (2012)

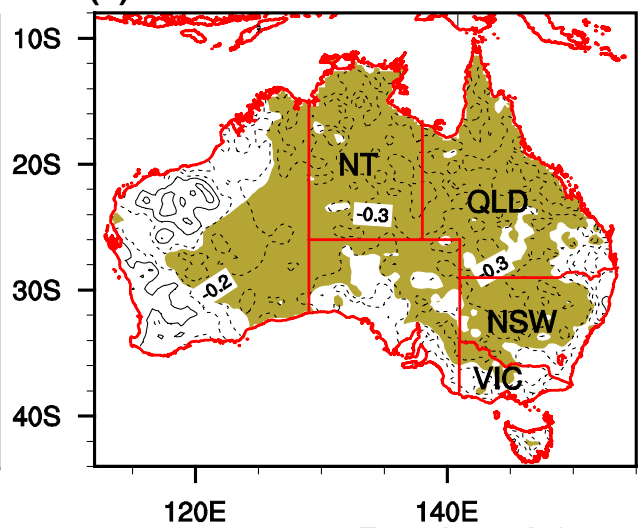

(f)

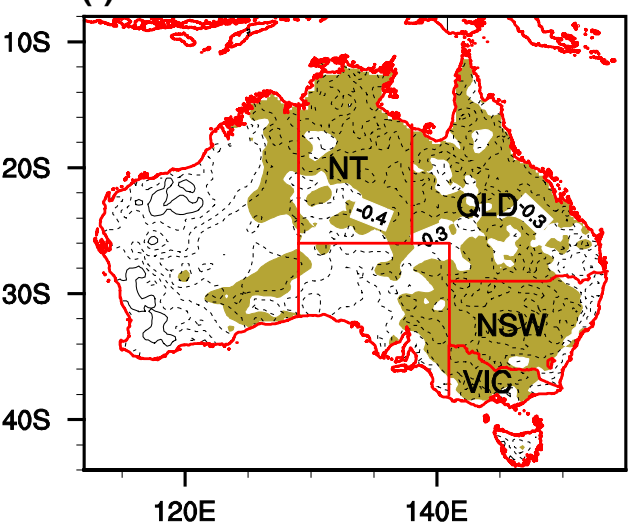

and rainfall data; $\mathbf{c}$ as a using the detrended NPO index and rainfall data. d-f The same as a-c, but using the NPO index defined by Furtado et al. (2012). Shading indicates correlation coefficients significant at the $95 \%$ confidence level; the contour interval is 0.1

rainfall relationship because it is based on the covariance SVD structure. All the above results strongly indicate that a positive NPO phase tends to be followed by a conspicuous drought in Australia during austral spring. To quantitatively measure the strength of the rainfall over eastern and northern Australia, four rainfall indices are defined as the area-averaged rainfall within the Northern Territory, and

defined in this study can better capture the NPO-Australian 
(a) NT Rain \& NPO indices

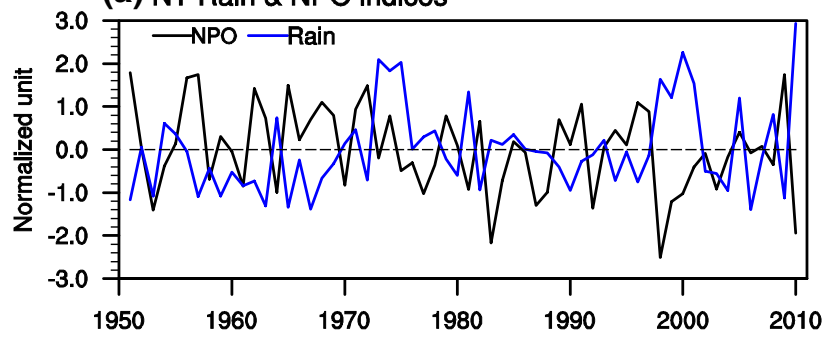

(b) QLD Rain \& NPO indices

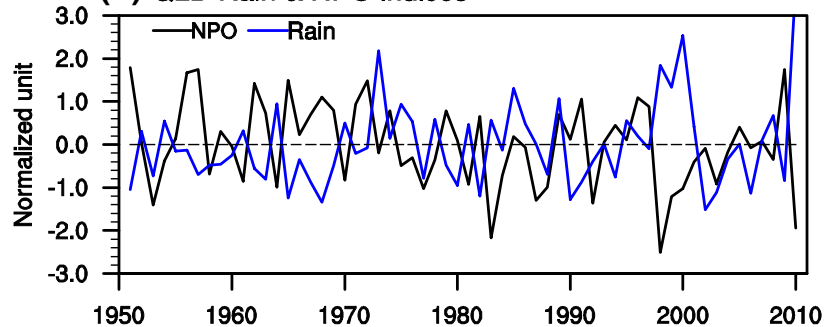

(c) NSW Rain \& NPO indices

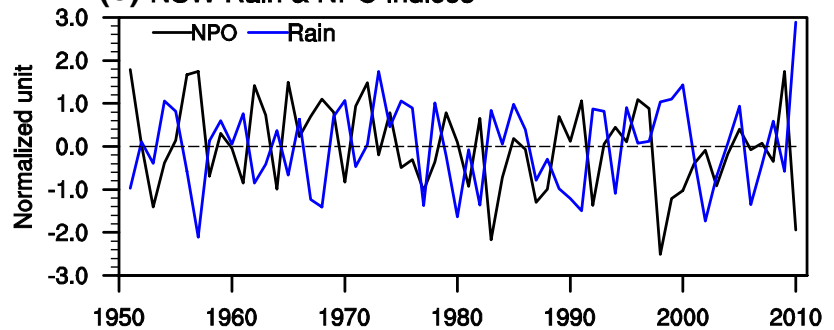

(d) VIC Rain \& NPO indices

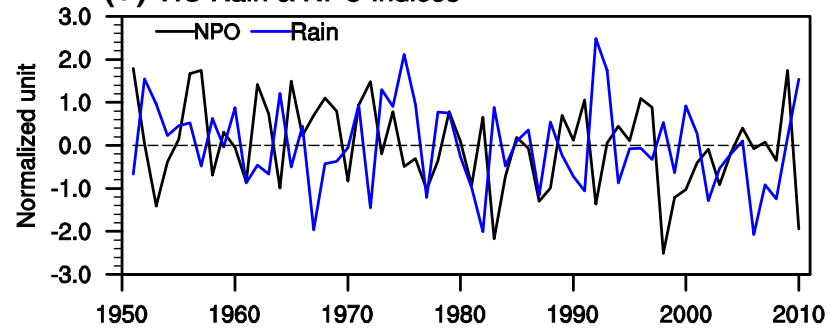

Fig. 4 Normalized time series of austral spring rainfall averaged over a the Northern Territory (NT), b Queensland (QLD), and c New South Wales (NSW) and d Victoria (VIC) for the period 1951-2010. The boreal winter NPO index is shown in each plot for comparison

the states of Queensland, New South Wales and Victoria, respectively (Fig. 3).

Figure 4 shows the normalized time series of rainfall indices over the Northern Territory, Queensland, New South Wales and Victoria in austral spring for the period 1951-2010. The normalized time series of NPO index in the preceding boreal winter is also shown in each plot of Fig. 4. All of the rainfall indices over the above-mentioned four regions display a significant out-of-phase connection with the NPO index. Their correlation coefficients reach $-0.50,-0.49,-0.48$ and -0.30 for the Northern Territory, Queensland, New South Wales and Victoria,
Table 2 Correlation coefficients between the boreal winter NPO index and the following austral spring rainfall in the Northern Territory (NT), and the states of Queensland (QLD), New South Wales (NWS) and Victoria (VIC)

\begin{tabular}{llll}
\hline Region & Raw & ENSO removed & Linear trend removed \\
\hline NT & $-0.50^{* * *}$ & $-0.53 * * *$ & $-0.46 * * *$ \\
QLD & $-0.49 * * *$ & $-0.52 * * *$ & $-0.46 * * *$ \\
NSW & $-0.48^{* * *}$ & $-0.44 * * *$ & $-0.48 * * *$ \\
VIC & $-0.30 * *$ & $-0.23 *$ & $-0.35 * * *$ \\
\hline
\end{tabular}

* Correlation significant at the $90 \%$ confidence level

** Correlation significant at the $95 \%$ confidence level

*** Correlation significant at the $99 \%$ confidence level

respectively (Table 2, column 1), all exceeding the $95 \%$ confidence level based on Student's $t$-test. In addition, significant negative correlations between the NPO index and rainfall indices still exist after removing the boreal wintertime ENSO influence and removing the long-term trend (Table 2, columns 2 and 3). These results are consistent with those shown in Fig. 3a-c, implying a significant negative relationship between the boreal winter NPO index and Australian rainfall in the following austral spring. The next question is how the NPO related circulation anomaly over the North Pacific crosses the equator to reach the Southern Hemisphere half a year later.

\section{Physical process for the influence of NPO on Australian rainfall}

It is generally acknowledged that atmosphere memory cannot persist for as long as half a year, while the SST memory is much longer. Previous studies have suggested that the boreal wintertime NPO forces tropical Pacific SST anomalies in the following winter via the "seasonal footprinting mechanism (SFM)" (e.g., Vimont et al. 2001, 2003a, b, 2009; Alexander et al. 2010). Hence, it is hypothesized that tropical Pacific SST anomalies may be a key link in connecting the boreal winter NPO and Australian rainfall in the following austral spring.

To investigate the possible mechanism linking the boreal winter NPO and the following austral spring Australian rainfall, we first examine the seasonal evolutions of NPOrelated SST and low-level wind anomalies from boreal winter to the following austral spring, shown in Fig. 5. In boreal winter, the $850 \mathrm{hPa}$ wind anomalies show a meridional dipole pattern over the North Pacific, with an anticyclonic anomaly in the mid-high latitude North Pacific, and a cyclonic anomaly in the subtropical north Pacific (Fig. 5a). During boreal winter, when intrinsic mid-latitude atmospheric variability is most energetic, the atmosphere 
(a)

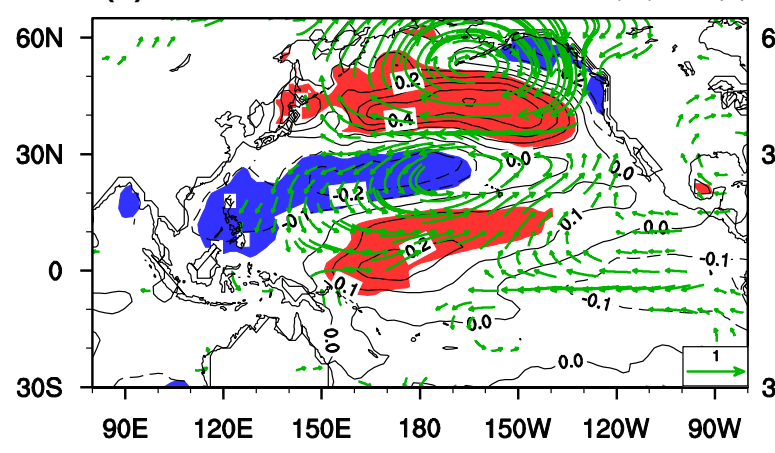

(c)

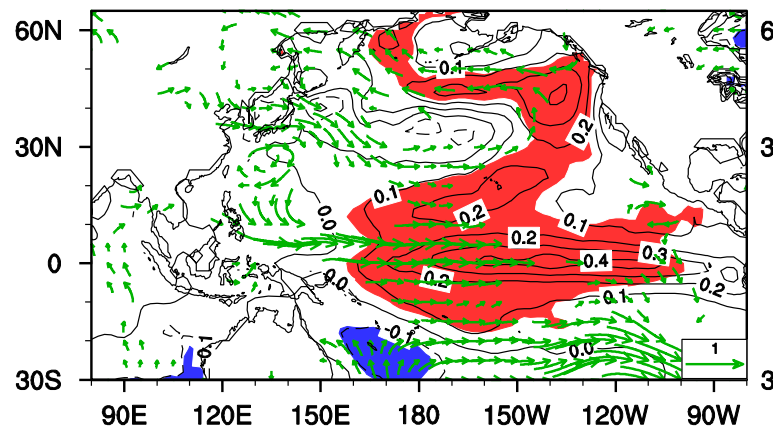

Fig. 5 Anomalies of a boreal winter $(\mathrm{ND}(-1) \operatorname{JFM}(0))$, b spring $(\mathrm{MAM}(0))$, and c summer $(\mathrm{JJA}(0))$, and d austral spring $(\mathrm{SON}(0))$ SST (contours) and $850 \mathrm{hPa}$ winds (vectors) obtained by regression on the normalized boreal winter NPO index during 1951-2010. Note that the boreal winter Nino3.4 index is linearly removed. Note that (b) $\operatorname{MAM}(0)$

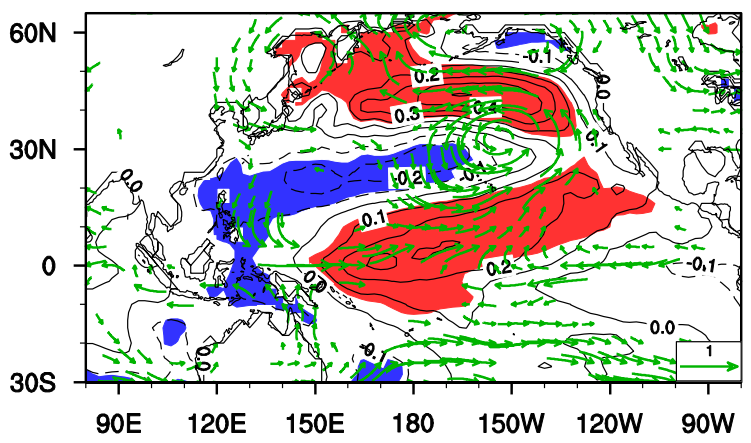

(d)

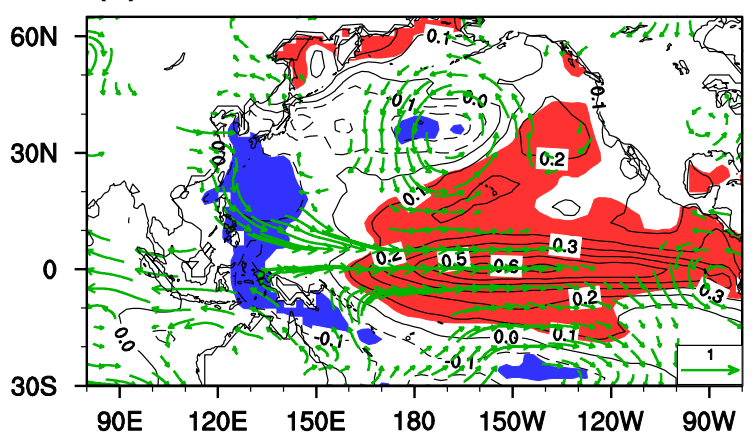

the linear trend of NPO is also removed. Shading denotes regions where the SST anomalies are significant at the $95 \%$ confidence level. The contour interval is $0.1{ }^{\circ} \mathrm{C}$. The wind scale is shown at the bottom right. Wind anomalies less than $0.1 \mathrm{~m} \mathrm{~s}^{-1}$ in both directions are not shown

in austral spring, the adjustment of the tropics by coupled dynamics produces an equatorially symmetric El Niño-like SST warming anomaly over the tropical central-eastern Pacific (Fig. 5d). Results shown in Fig. 5 capture well the SFM features reported in previous studies (e.g., Vimont et al. 2003a, b; Alexander et al. 2010), which confirm that the boreal winter NPO leads to tropical Pacific SST anomalies in the following austral spring.

In order to investigate the atmospheric circulation patterns in austral spring, we calculated the regression fields of velocity potential and vertical velocity anomalies on the boreal winter NPO index as shown in Fig. 6. At $850 \mathrm{hPa}$, there is a zone of convergence in the tropical eastern Pacific, flanked by a zone of divergence to the west of the dateline (Fig. 6a). Australia lies under the anomalous divergence zone. In contrast, a reverse velocity potential anomalies appears at $200 \mathrm{hPa}$, with a divergence center over the tropical eastern Pacific and a convergence center over the tropical western Pacific (Fig. 6b), indicating a baroclinic atmospheric response. This means that the upper level convergence, accompanied by lower level divergence over the tropical western Pacific and northern Australian region, directly induces an anomalous subsiding motion there 
(a)

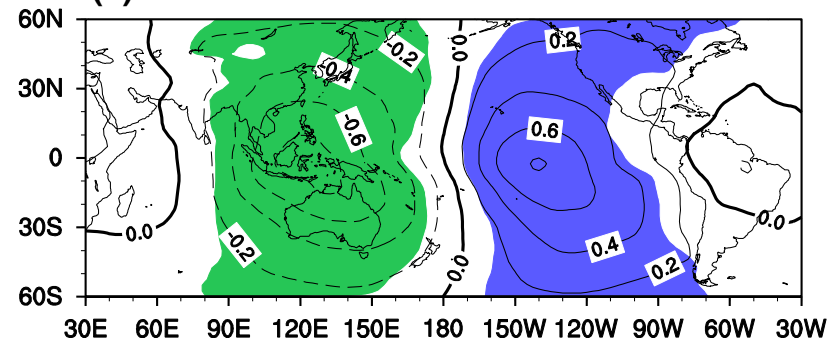

(b)

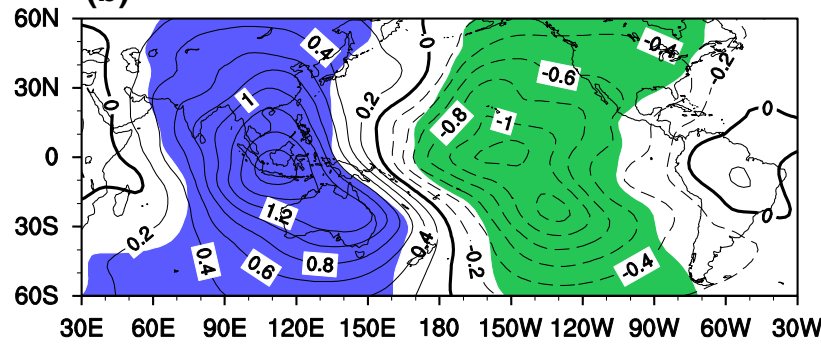

(c)

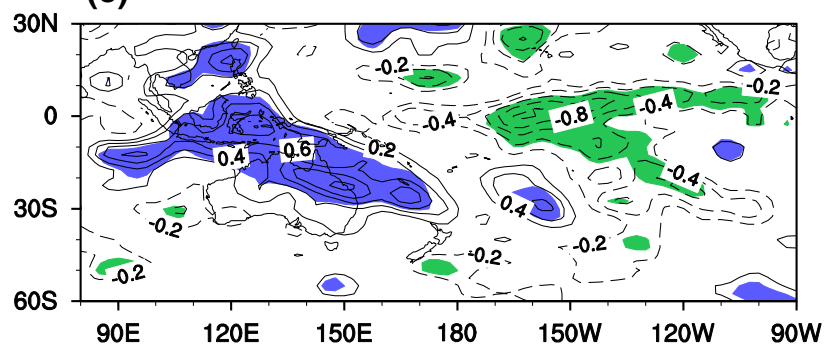

Fig. 6 Anomalies of austral spring a $850 \mathrm{hPa}$ velocity potential, b $200 \mathrm{hPa}$ velocity potential, and c $500 \mathrm{hPa}$ vertical $p$-velocity obtained by regression on the normalized boreal winter NPO index. Note that the boreal winter Nino3.4 index has been linearly removed in constructing this figure. The shading denotes regions where anomalies are significant at the $95 \%$ confidence level. The contour interval is $0.2 \times 10^{6} \mathrm{~m}^{2} \mathrm{~s}^{-1}$ in $\mathbf{a}$ and $\mathbf{b}$, and $0.2 \times 10^{-2} \mathrm{~Pa} \mathrm{~s}^{-1}$ in $\mathbf{c}$

(Fig. 6c). Meanwhile, significant ascending motion anomalies are observed in the tropical central-eastern Pacific (Fig. 6c). The distributions of velocity potential anomalies at $850 \mathrm{hPa}$ and $200 \mathrm{hPa}$, and vertical velocity anomalies at $500 \mathrm{hPa}$ bear a close resemblance with those of an El Niño event (e.g., Ropelewski and Halpert 1987; Wang 2004). This perhaps results from the significant positive SST anomalies over the tropical central-eastern Pacific, and negative SST anomalies over the tropical and off-equator western Pacific associated with the preceding boreal wintertime NPO through a Gill-like atmospheric response (Fig. 5d) (Matsuno 1966; Gill 1980).

To further understand the atmospheric links associated with the connection between NPO index and Australian rainfall, Fig. 7a shows the Walker circulation anomalies regressed on the NPO index during austral spring. The Walker circulation is depicted by zonal and meridional winds averaged between $5^{\circ} \mathrm{S}$ and $5^{\circ} \mathrm{N}$. The anomalous
Walker circulation shows air rising in the equatorial eastern Pacific, flowing westward aloft and sinking in the equatorial western Pacific around $125^{\circ} \mathrm{E}$, and then flowing westward and eastward. One branch returns to the eastern Pacific in the lower troposphere (Fig. 7a). This demonstrates a weakened Walker circulation cell when SST is above normal over the tropical central-eastern Pacific, consistent with the findings reported in previous studies (e.g., Ropelewski and Halpert 1987; Wang 2004). The western descending branch, located over equatorial western Pacific, leads to suppressed convection and moist air rising. Hence, significant negative surface precipitable water anomalies are seen over Indonesia, extending southeastward to northern and eastern Australia, with the maximum center located near $15^{\circ} \mathrm{S}, 140^{\circ} \mathrm{E}$ (Fig. $7 \mathrm{~b}$ ). In particular, about two-thirds of Australia is under the control of negative surface precipitable water anomalies (Fig. 7b), which favors negative rainfall anomalies (Fig. 3).

From analyzing the atmospheric circulation anomalies associated with the NPO (Figs. 6, 7), it is hypothesized that the NPO affects the Australian rainfall during austral spring mainly through the simultaneous tropical Pacific SST anomalies, which are triggered via the SFM (Fig. 5). An interesting phenomenon is that if the partial-regression approach is used to remove the tropical central Pacific SST signal in austral spring, the NPO-related atmospheric circulation and precipitation anomalies all become indistinct and insignificant. Here, the tropical central Pacific SST signal is removed by subtracting the linear component of the area mean SST anomalies over the region $\left(5^{\circ} \mathrm{S}-5^{\circ} \mathrm{N}\right.$, $160^{\circ} \mathrm{E}-150^{\circ} \mathrm{W}$ ) regressed against the NPO index. Figure 8 displays the partial regression fields of velocity potential anomalies at 850 and $200 \mathrm{hPa}$, and vertical velocity anomalies at $500 \mathrm{hPa}$. This indicates that, when the effect of the NPO-related tropical central Pacific SST warming is removed, the significant upper level convergence and lower level divergence over the tropical western Pacific disappear; over the eastern Pacific, the significant upper level divergence and lower level convergence also disappear (Fig. 8a, b), suggesting a distinct Walker circulation change. Meanwhile, the middle level vertical velocity anomalies over the tropical western Pacific and northern Australia are reduced in amplitude and become insignificant (Fig. 8c). To further verify the speculation that the anomalous Walker circulation induced by tropical central Pacific SST anomalies plays an important role in relaying the influence of boreal winter NPO on Australian rainfall, we show in Fig. 9 the partial regression patterns of Walker circulation upon the NPO index with tropical central Pacific SST anomalies linearly removed. It shows that the anomalous Walker circulation becomes much weaker and insignificant when the NPO-related tropical central Pacific SST warming is removed (Fig. 9). Hence, this further confirms that the 
Fig. 7 a Pressure-longitude section showing the austral spring anomalies of $5^{\circ} \mathrm{S}-5^{\circ} \mathrm{N}$ averaged zonal $\left(\mathrm{m} \mathrm{s}^{-1}\right)$ and vertical $\left(10^{-3} \mathrm{~Pa} \mathrm{~s}^{-1}\right)$ winds obtained by regression on the normalized boreal winter NPO index. b Austral spring surface precipitable water content $\left(\mathrm{kg} \mathrm{m}^{-2}\right)$ anomalies obtained by regression on the normalized boreal winter NPO index. Note that boreal winter Nino3.4 index is removed. Shading in a denotes regions where vertical wind anomalies are significant at the $95 \%$ confidence level. Only anomalies of surface precipitable water significant at the $95 \%$ confidence level are shown in b

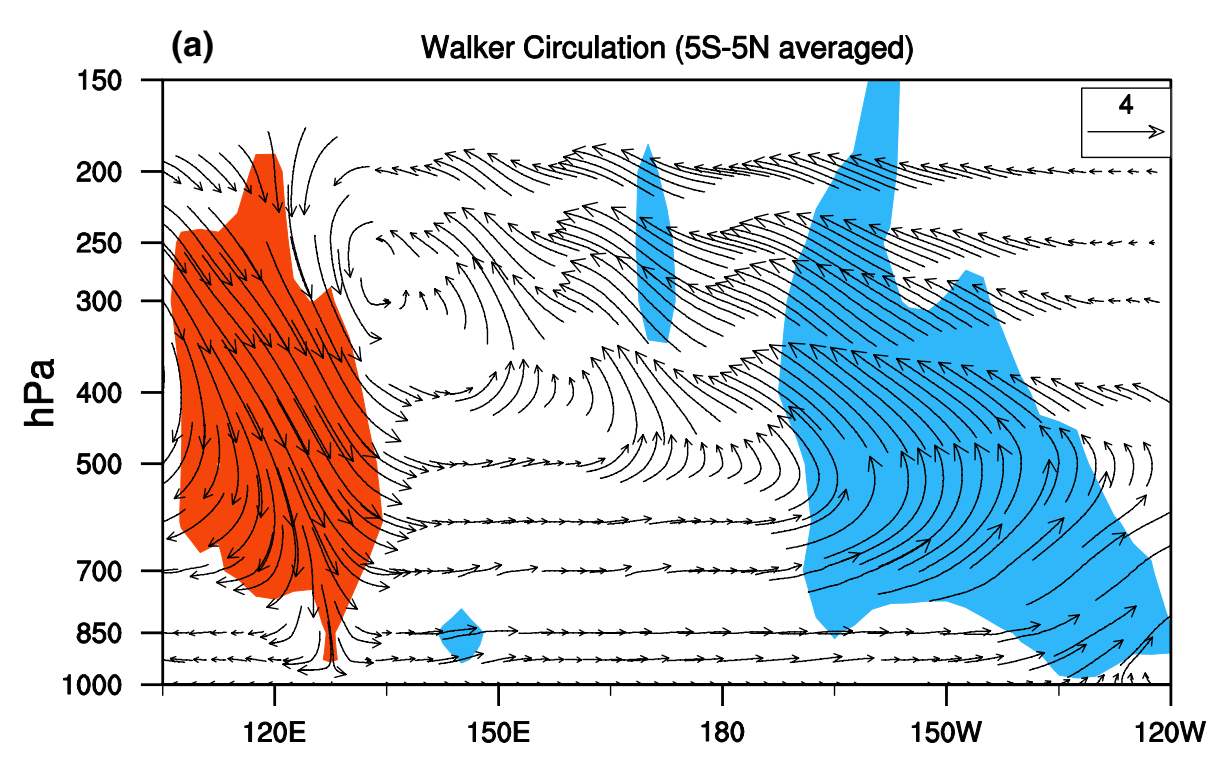

(b)

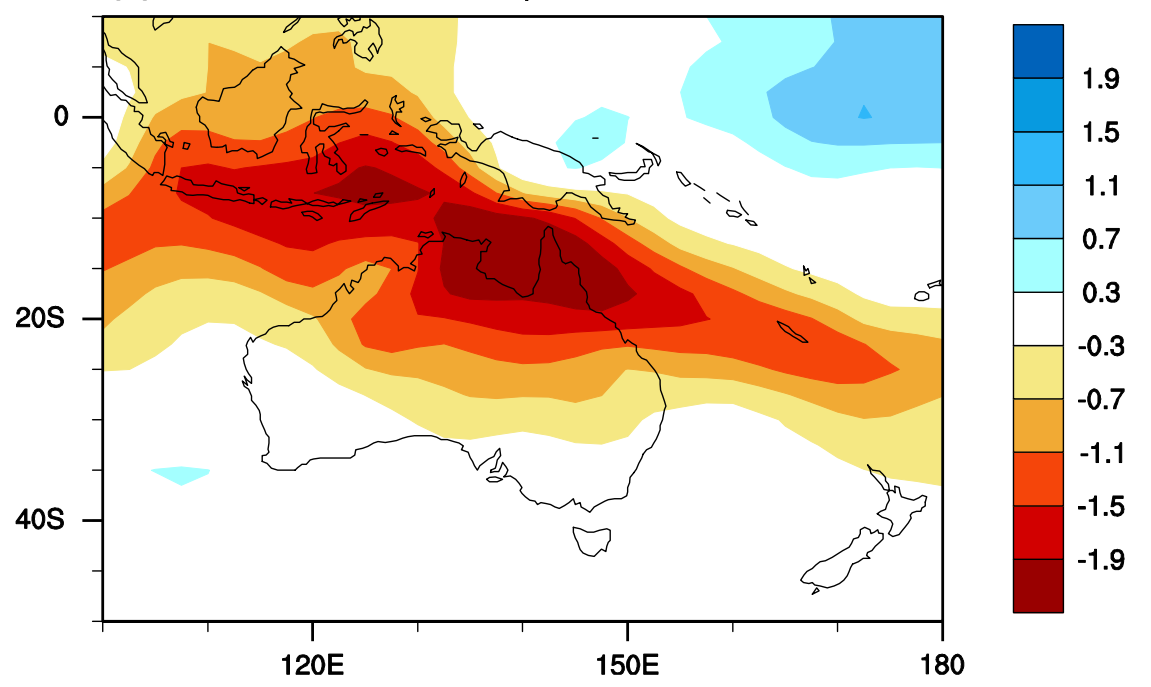

anomalous Walker circulation plays a key role in linking boreal winter NPO and Australian rainfall in austral spring.

A similar feature also exists in Australian rainfall anomalies, as shown in Fig. 10. After removing the NPO-related SST anomalies over the tropical central Pacific, despite a few fragmentary and small patches in the northeastern Northern Territory and eastern coast of Queensland, significant correlation coefficients between NPO index and rainfall anomalies over much of the continent become unclear and insignificant (Fig. 10). Because SST anomalies in the tropical Pacific region $\left(5^{\circ} \mathrm{S}-5^{\circ} \mathrm{N}, 160^{\circ} \mathrm{E}-150^{\circ} \mathrm{W}\right)$ is generally used to characterize the ENSO variability. To avoid confusion, we have also examined the above results shown in Figs. 8, 9 and 10 by removing the effect of preceding boreal spring SST anomalies in the subtropical region $\left(5^{\circ}-15^{\circ} \mathrm{N}\right.$, $\left.170^{\circ} \mathrm{E}-160^{\circ} \mathrm{W}\right)$. SST anomalies in this region have been suggested to play a key role in connecting the NPO and the tropical central-eastern Pacific SST anomalies (Anderson 2003; Vimont et al. 2003b). It is found that preceding winter NPO-related anomalies of Walker circulation and Australian rainfall are weak and insignificant (Figures not shown), consistent with the results obtained by removing the tropical Pacific SSTA (Figs. 8, 9, 10). Insignificant anomalies of Walker circulation and Australian rainfall are attributed to the fact that SST anomalies over the tropical central-eastern Pacific in SON(0) are weak and insignificant after removing the SST anomalies in the subtropical footprinting region (not shown). Above results further confirm the important role of tropical central Pacific SST anomalies generated by the preceding winter NPO through the SFM in influencing the Australian rainfall anomalies, and also demonstrate the hypotheses that the preceding winter NPO can influence the following austral spring rainfall variability in Australia via modulating the Walker circulation. 
(a)

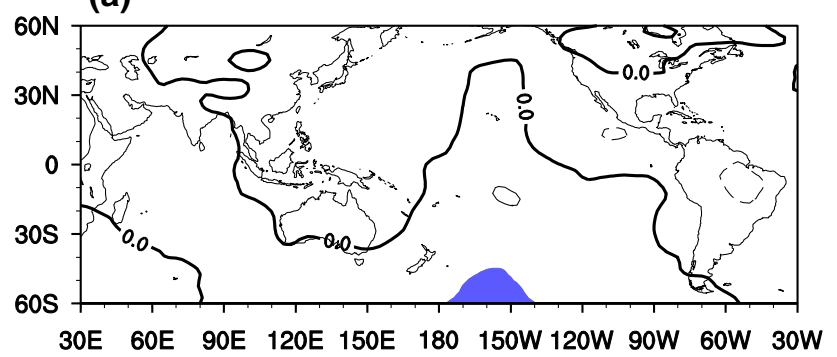

(b)

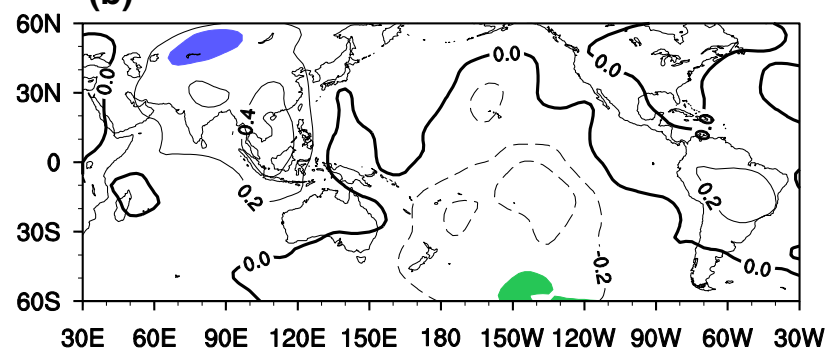

(c)

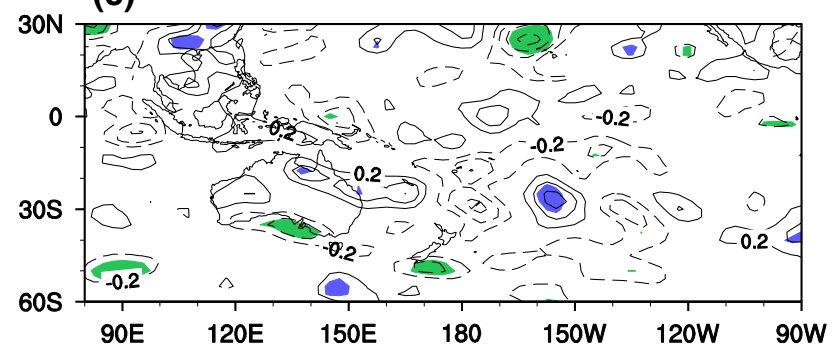

Fig. 8 As Fig. 5, but for the partial regression patterns with the austral spring tropical central Pacific SST anomalies $\left(5^{\circ} \mathrm{S}-5^{\circ} \mathrm{N}\right.$, $160^{\circ} \mathrm{E}-150^{\circ} \mathrm{W}$ ) removed

\section{NPO contribution to the Australian spring rainfall trend}

This section discusses the influence of the NPO on Australian spring rainfall, focusing on the long-term trend. Figure 11a shows the regional rainfall trend over the Australian continent in austral spring during 1951-2010. It is evident that there is a wetting trend over the majority of the continent, and a drying trend over the regions of Victoria and southern New South Wales (Fig. 11). The significant rainfall increasing trends are mainly centered over the Northern Territory and Queensland, extending westward to Western Australia. The maximum positive trend value reaches about $12 \mathrm{~mm}$ decade $^{-1}$ in central Queensland (Fig. 11a). We calculate the trends of area-averaged rainfall in the Northern Territory, Queensland, New South Wales and Victoria, respectively (Fig. 11b). The Northern Territory rainfall has a positive trend with a slope of $5.7 \mathrm{~mm}$ decade $^{-1}$ in the period 1951-2010, significant at the 0.05 level. A similar increasing trend is also detected in Queensland rainfall, again with a slope of $5.7 \mathrm{~mm}$ decade $^{-1}$, significant at the 0.10 level. It should be noted that this study focused on the period 1951-2010 and the trend may be, to some extent, depended on the selected time period. In addition, New South Wales rainfall shows an insignificant wetting trend $\left(2.3 \mathrm{~mm}\right.$ decade $\left.^{-1}\right)$, while Victoria rainfall shows an insignificant drying trend $\left(-4.4 \mathrm{~mm} \mathrm{decade}^{-1}\right)$. In the following, we focus on the significant increasing trends of the Northern Territory and Queensland rainfalls.

As demonstrated in Sects. 3 and 4, there is a close outof-phase connection between the boreal wintertime NPO
Fig. 9 As Fig. 7a, but for the partial regression patterns of Walker circulation with the austral spring tropical central Pacific SST anomalies $\left(5^{\circ} \mathrm{S}-\right.$ $\left.5^{\circ} \mathrm{N}, 160^{\circ} \mathrm{E}-150^{\circ} \mathrm{W}\right)$ removed

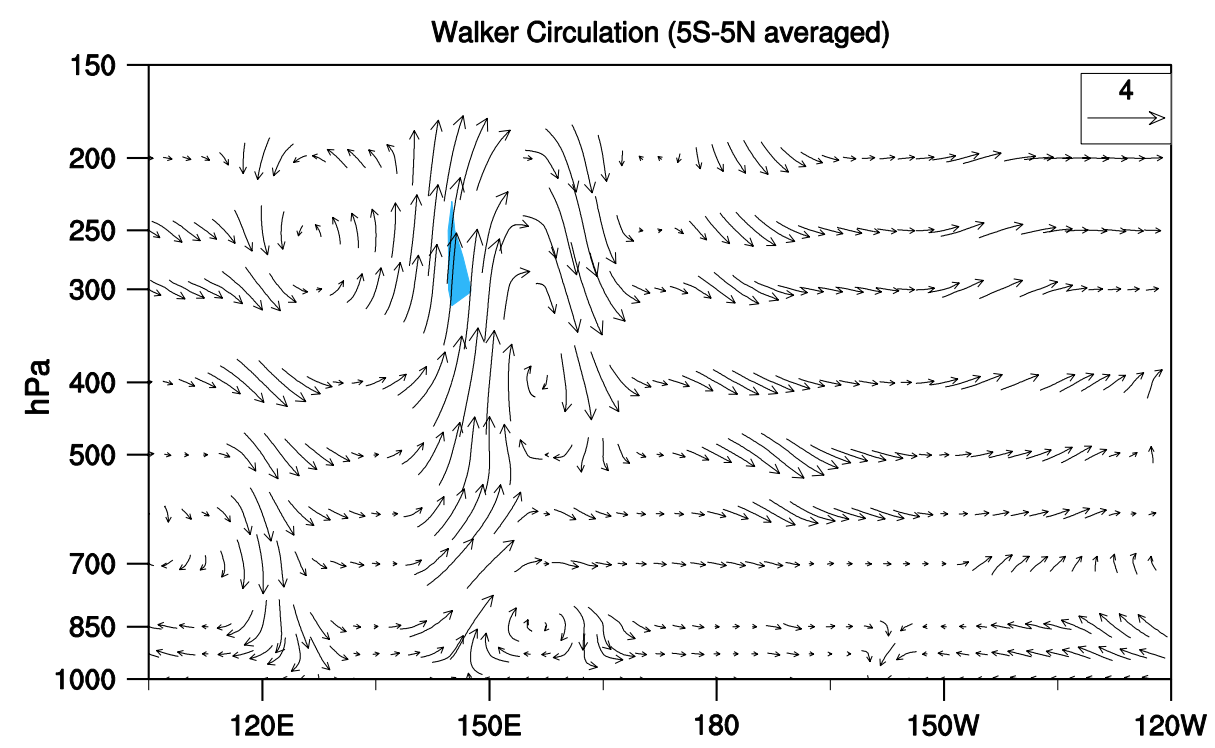




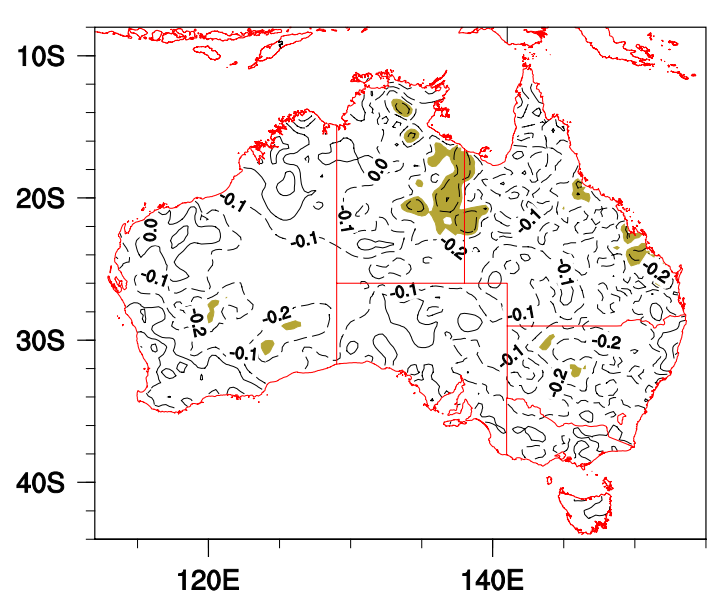

Fig. 10 The partial correlation map between the NPO index in the preceding boreal winter and Australian rainfall in austral spring, with the austral spring tropical central Pacific SST anomalies $\left(5^{\circ} \mathrm{S}-5^{\circ} \mathrm{N}\right.$, $160^{\circ} \mathrm{E}-150^{\circ} \mathrm{W}$ ) removed

and following austral spring rainfall in Australia in interannual variability. A positive NPO year is often followed by a less than average rainfall, and an above average rainfall for a negative NPO year, in both the Northern Territory and Queensland. The ENSO also significantly influences the interannual Australian rainfall variability, as demonstrated by previous studies (e.g., McBride and Nicholls 1983; Nicholls et al. 1996; Taschetto and England 2009). A further question is whether the NPO and ENSO both contribute to the significant increasing trends in the Northern Territory and Queensland rainfalls during 1951-2010. To examine the potential contributions of the NPO and ENSO, we first check the long-term trends of the boreal winter NPO index and austral spring ENSO indices during 1951-2010 (Fig. 12). The ENSO is unlikely to bring more rainfall, and cannot explain the significant increasing trends in the Northern Territory and Queensland rainfalls because the linear trend of the ENSO index is insignificant (Fig. 12b). In contrast, the boreal winter NPO index has a significant weakening trend $\left(-0.29 \mathrm{mb} \mathrm{decade}^{-1}\right)$, significant at the $95 \%$ confidence level (Fig. 12a). Since ENSO events are not responsible for the wetting trends of the Northern Territory and Queensland rainfalls, and given the significant decreasing trend in NPO index, we focus on the possible influence of NPO on Australian rainfall trends.

Figure $13 \mathrm{a}, \mathrm{b}$ show the time series, and their linear trends of residuals from the Northern Territory and Queensland rainfall predicted with linear regressions using the NPO index as predictor, respectively. The residuals of the Northern Territory and Queensland rainfall, after removal of the NPO contribution, exhibit much more flat trend lines, both of which become insignificant at the $90 \%$ confidence level (Fig. 13). Therefore, the decreasing trend of NPO is linked to the increasing trend of the Northern Territory and Queensland rainfalls during 1951-2010. Following the study of Nicholls (2010), the partial correlation between rainfall and the "year" of observation, controlling for the impact of the remote index of a specific climate mode can be used to demonstrate whether this mode can be considered as a cause of the rainfall trend. If the partial correlation is close to zero and insignificant, it indicates that much of the rainfall trend is linked to the trend of the mode. The partial correlations between rainfall and "year", after removing the influence of NPO, are 0.15 and 0.11 in Northern Territory and Queensland, respectively. These correlations are small and not significant at the $90 \%$ confidence level, although not quite as close to zero. These results are generally consistent with those obtained from Fig. 13, with the residual showing a more flat trend line.

To quantify how much of the rainfall wetting trend is associated with the decreasing NPO, the contributions of NPO to the Northern Territory and Queensland rainfall trends are calculated and listed in Table 3. First,
Fig. 11 a Linear trend of the austral spring rainfall for the period 1951-2010. Linear trends significant at the $90 \%$ confidence level are stippled with dots. b Time series and linear trends of rainfall in the Northern Territory (NT), Queensland (QLD), New South Wales (NSW) and Victoria (VIC). In b single asterisk denotes a linear trend significant at the $90 \%$ confidence level, and double asterisk likewise at a $95 \%$ confidence level (a) $1951-2010$

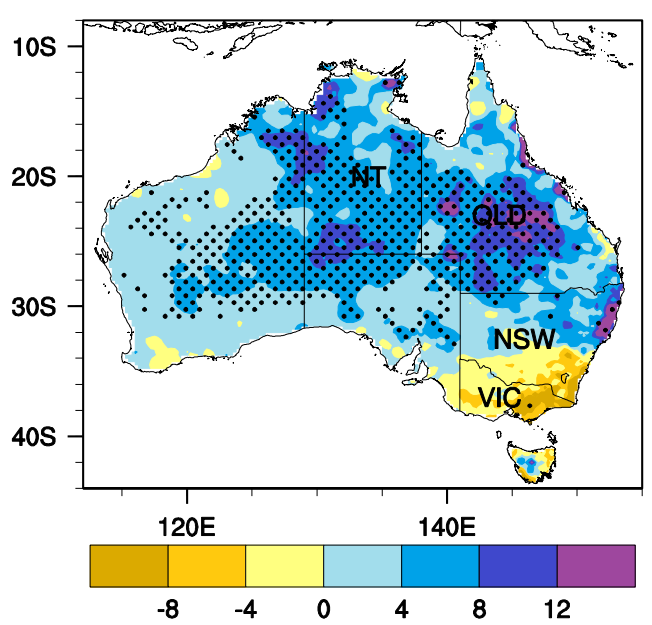

(b)

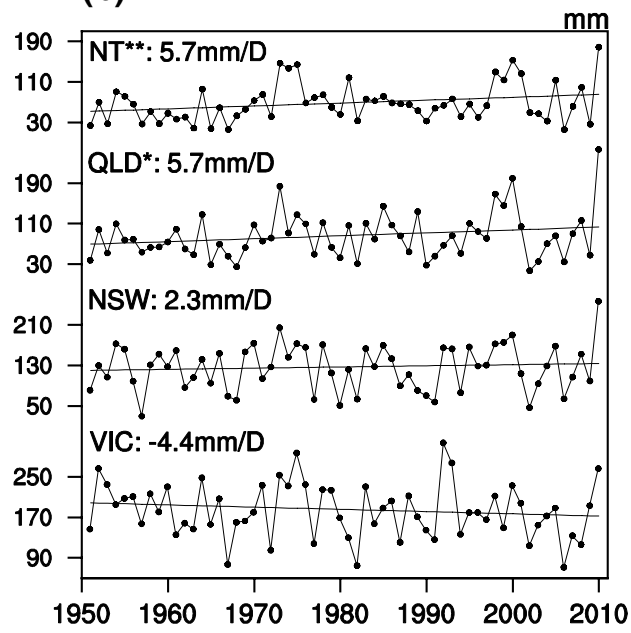



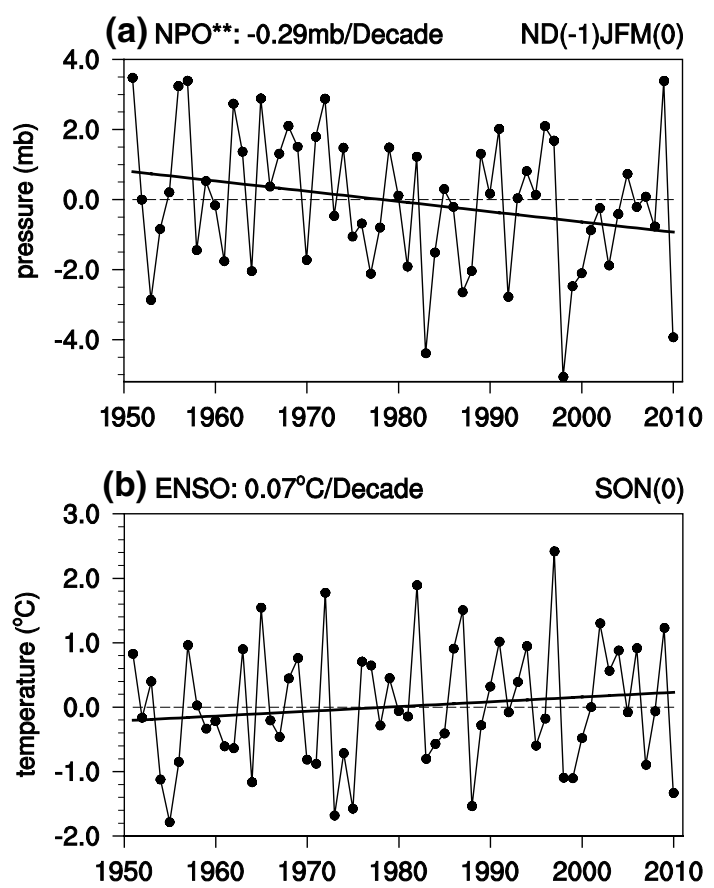

Fig. 12 Time series and linear trends of the a boreal winter NPO index and b austral spring Nino3.4 index during 1951-2010. Single asterisk denotes a linear trend significant at the $90 \%$ confidence level, and double asterisk likewise at a $95 \%$ confidence level

year-to-year differences were calculated for time series of the NPO index and rainfall, and then linear regression and correlation were calculated between them (Nicholls 2010; Li et al. 2013). The linear regression between the yearto-year differences of NPO index and rainfall allow the

\section{(a) NT}

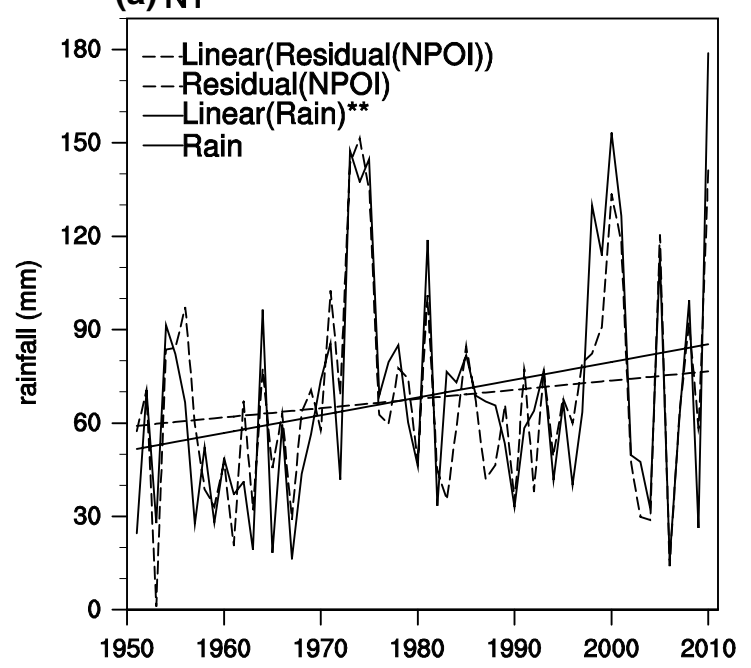

Fig. 13 Time series of austral spring rainfall in a the Northern Territory (NT) and b Queensland (QLD) during 1951-2010. The time series of residuals from rainfall predicted with linear regressions using boreal winter NPO index as a predictor are also shown, with the estimation of the rainfall trend expected from the trend in NPO index through the relationship between rainfall and NPO index. Accordingly, the sensitivity of rainfall to NPO index is defined as the slope of the NPO index in the fitted linear regression model for the relationship between year-to-year differences of rainfall and NPO index. Thus, assuming that the relationship derived from the year-toyear differences operates on a multidecadal time scale, the rainfall trend induced by the NPO can be estimated as the product of the sensitivity and the trend of the NPO. Finally, the contribution of the NPO is measured as the ratio of the NPO-induced trend value to the observed rainfall trend value. Results show that the wetting trends of the Northern Territory and Queensland rainfall induced by the NPO are 2.6 and $3.3 \mathrm{~mm}$ decade $^{-1}$, respectively (Table 3). Therefore, the decrease of the NPO contributed 46.0 and $57.5 \%$ to the increasing trends of the Northern Territory and Queensland rainfalls in the period 19512010, respectively.

The physical effect of the NPO on the Australian rainfall trend may be embedded in the change of the Walker circulation. Figure 14 presents the difference of Walker circulation anomalies between the periods 1981-2010 and 1951-1980. Significant downward motion anomalies can be observed over the equatorial eastern Pacific and notable upward motion anomalies can be seen over equatorial western Pacific (Fig. 14). It indicates that strength of the Walker circulation over the tropical Pacific is stronger during the latter (19812010) than earlier epoch (1951-1980). The strengthened Walker circulation in the latter period could cause an

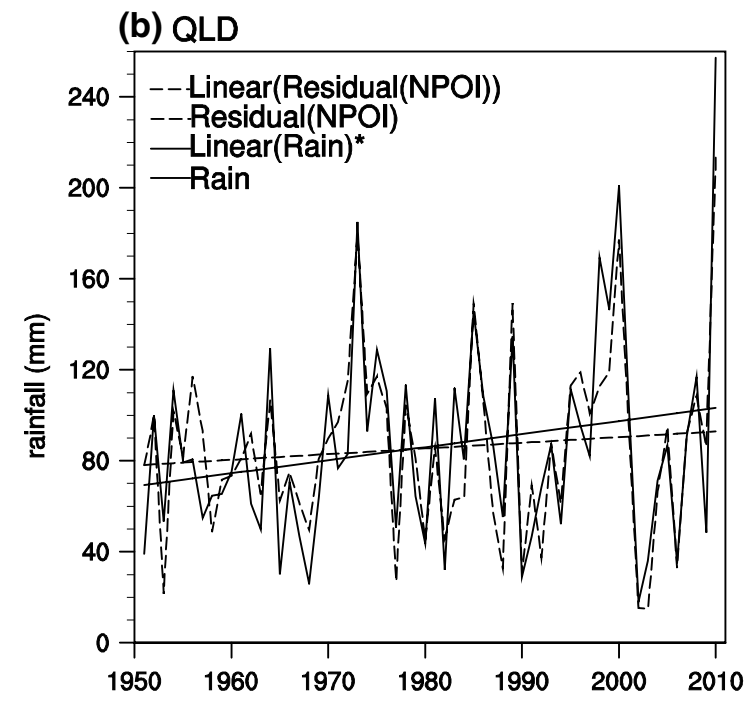

mean rainfall value added back in. Linear trends are all shown for all variables. Single asterisk denotes a linear trend significant at the $90 \%$ confidence level, and double asterisk likewise at a $95 \%$ confidence level 
Table 3 Sensitivity of rainfall in the Northern Territory and Queensland associated with the NPO index as well as its trend and induced rainfall trend during 1951-2010

\begin{tabular}{lcc}
\hline & Northern Territory & Queensland \\
\hline $\begin{array}{l}\text { Correlation (year-to-year difference } \\
\text { data) }\end{array}$ & $\mathbf{- 0 . 5 2}$ & $\mathbf{- 0 . 5 3}$ \\
Sensitivity $\left(\mathrm{mm} \mathrm{mb}^{-1}\right)$ & $\mathbf{- 8 . 9 7}$ & $\mathbf{- 1 1 . 3 0}$ \\
Trend $\left(\mathrm{mb} \mathrm{decade}^{-1}\right.$ ) & $\mathbf{- 0 . 2 9}$ & $\mathbf{- 0 . 2 9}$ \\
Induced rain trend (mm decade & -1 & 3.3 \\
Contribution $(\%)$ & 2.6 & 57.5 \\
\hline
\end{tabular}

Sensitivity is estimated by applying the regression (slope) between year-to-year changes (removing the linear trend) in rainfall and NPO index; the induced rainfall trend is the product of the sensitivity and the NPO index trend during 1951-2010. Correlations or regressions significant at the $95 \%$ confidence level are in bold

enhanced ascending motion and more moisture over the tropical western Pacific and northern part of Australia, leading to significant increase in rainfall over the Northern Territory and Queensland. We have also examined the difference of Walker circulation anomalies between NPO low and high years (Figure not shown), and the results display similar features as shown in Fig. 14. Therefore, the change of Walker circulation associated with the NPO contributed to the increase of both the Northern Territory and Queensland rainfall in the recent six decades.

\section{Summary}

In this study, we demonstrate that the boreal winter $(\mathrm{ND}(-1) \mathrm{JFM}(0)) \mathrm{NPO}$ is significantly correlated with
Australian rainfall anomalies in the following austral spring $(\mathrm{SON}(0))$ on the interannual time scale. If the boreal winter NPO is in its positive phase, rainfall over the regions of the Northern Territory, Queensland, New South Wales and Victoria tends to be below average in austral spring, and for a negative phase above average in austral spring.

The physical process responsible for the influence of boreal winter NPO on the Australian rainfall in the following austral spring is further examined, and a schematic of the physical process is shown in Fig. 15. Tropical Pacific SST anomalies play an important role in relaying the NPO influence on Australian spring rainfall anomalies. The boreal winter NPO influences the tropical Pacific SST anomalies via the seasonal footprinting mechanism, as demonstrated by previous studies. Boreal winter NPOinduced SST anomalies in austral spring over the tropical Pacific further influence the Australian spring rainfall anomalies via an anomalous Walker circulation (Fig. 15).

The detailed physical processes for the influence of boreal winter NPO on Australian spring rainfall can be summarized as follows. When the NPO is in its positive phase, the anomalous winds are from the west opposing the trade winds over the central and eastern subtropical Pacific. Thus, the upward latent heat is reduced by a decreased wind speed and hence causes the warming in the upper ocean. This NPO-related SST warming anomaly over the subtropical northern Pacific persists into late spring and summer via a positive air-sea feedback mechanism (Xie and Philander, 1994). In turn, these force a pattern of atmospheric circulation anomalies, including westerly wind stress anomalies, along the equatorial western Pacific. These subsequently lead to SST warming anomalies in austral spring over the tropical central-eastern Pacific by triggering an eastward propagating and downwelling Kelvin wave (Barnett et al.
Fig. 14 Pressure-longitude section showing composite anomalies of austral spring $5^{\circ} \mathrm{S}-5^{\circ} \mathrm{N}$ averaged zonal $\left(\mathrm{m} \mathrm{s}^{-1}\right)$ and vertical $\left(10^{-3} \mathrm{~Pa} \mathrm{~s}^{-1}\right)$ winds between the period 1981-2010 and 1951-1980. The shading denotes regions where differences of vertical wind anomalies are significant at the $90 \%$ confidence level

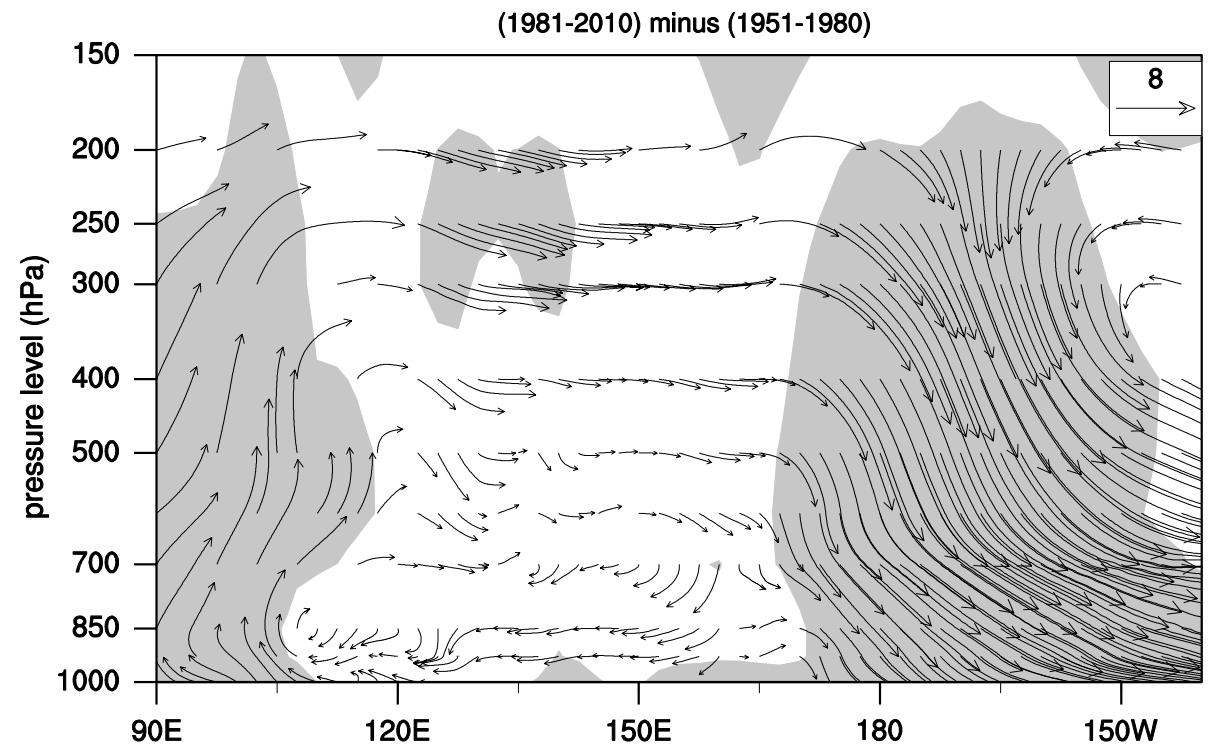


Fig. 15 Schematic of the physical mechanism for the influence of the preceding boreal winter $(\mathrm{ND}(-1) \mathrm{JFM}(0)) \mathrm{NPO}$ on the following austral spring $(\mathrm{SON}(0))$ rainfall in Australia. a Boreal wintertime and $\mathbf{b}$ austral spring. Green contours in a denote boreal winter NPO SLP anomalies with a dipole spatial pattern; and vectors denote $850 \mathrm{hPa}$ wind anomalies. Red and blue shading denotes positive and negative SST anomalies in $\mathbf{a}$ and $\mathbf{b}$

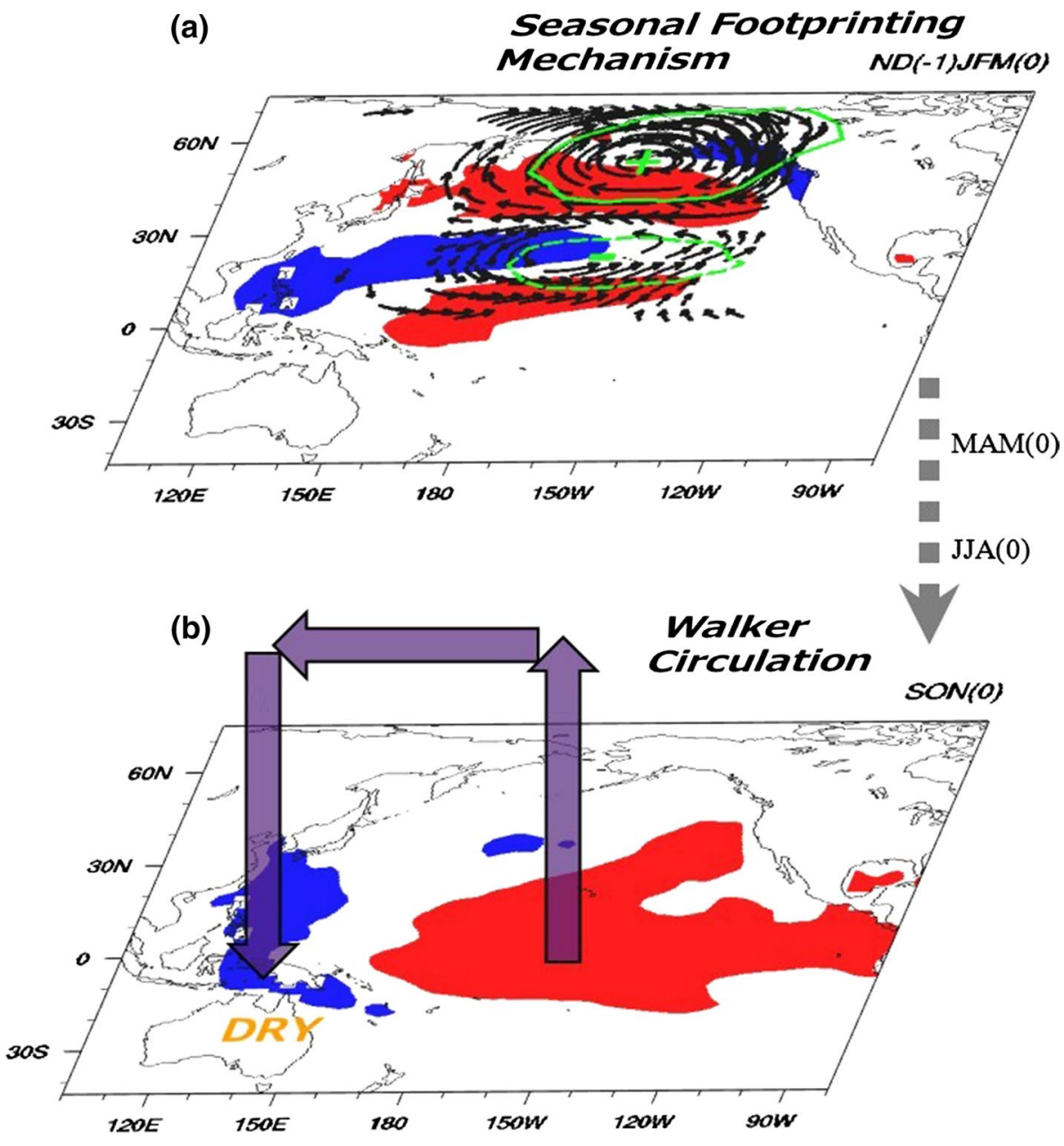

1989; Weisberg and Wang 1997; Vimont et al. 2003a, b; Alexander et al. 2010). Warming of SST in austral spring over the tropical central-eastern Pacific induces an anomalous Walker circulation, with its western subsiding branch over Australia, suppressing convection and reducing rainfall in northern and eastern Australia. Furthermore, the correlation between boreal winter NPO and Australian spring rainfall anomalies becomes insignificant, when NPOinduced SST warming anomalies in austral spring over the tropical central-eastern Pacific are linearly removed. This also indicates that the tropical central-eastern Pacific SST plays a key role in memorizing and relaying the influence of boreal winter NPO on Australian spring rainfall anomalies. It should be noted that other cross-equatorial impact mechanisms (e.g., Wu et al. 2009, 2015) may also play a role in linking NPO and Australian rainfall, which should be further investigated in the future.

Besides the significant interannual relationship between the NPO and Australian spring rainfall, we also examine the role of the NPO in contributing to the longterm trend of austral spring rainfall. It is found that the Northern Territory $\left(5.7 \mathrm{~mm}\right.$ decade $^{-1}$ ) and Queensland $\left(5.7 \mathrm{~mm} \mathrm{decade}{ }^{-1}\right)$ rainfall in austral spring has a significant wetting trend during 1951-2010, while the trends of austral spring rainfall over New South Wales $(2.3 \mathrm{~mm}$ decade $^{-1}$ ) and Victoria $\left(-4.4 \mathrm{~mm} \mathrm{decade}{ }^{-1}\right)$ are insignificant. Further analysis shows that the ENSO cannot explain the long-term trend of the Northern Territory and Queensland although it is closely connected with the variability of Australian rainfall on the interannual timescale. In contrast, it is found that the boreal winter NPO could contribute significantly to the increase of austral spring rainfall over the Northern Territory and Queensland. Results show that the NPO has contributed as much as 46.0 and $57.5 \%$ to the increasing trends of the Northern Territory and Queensland rainfalls in the period 19512010, respectively. When the NPO decreases, the Walker circulation is strengthened, thus enhancing ascending motion and increased rainfall over the Northern Territory and Queensland on a long-term timescale. However, caution is recommended regarding the trend results obtained in this study as the austral spring rainfall trends in Australia have a dependency on the choice of the selected time period. 
Acknowledgments We thank three anonymous reviewers for their constructive suggestions and comments, which helped to improve the paper. This study is supported by the National Basic Research Program of China (No. 2012CB955202). L. S. received a support from China Scholarship Council under the Joint-PhD program for conducting research at CSIRO. Y. L. was supported by the Indian Ocean Climate Initiative.

Open Access This article is distributed under the terms of the Creative Commons Attribution 4.0 International License (http://creativecommons.org/licenses/by/4.0/), which permits unrestricted use, distribution, and reproduction in any medium, provided you give appropriate credit to the original author(s) and the source, provide a link to the Creative Commons license, and indicate if changes were made.

\section{References}

Alexander MA, Vimont DJ, Chang P, Scott JD (2010) The impact of extratropical atmospheric variability on ENSO: testing the seasonal footprinting mechanism using coupled model experiments. J Clim 23:2885-2901

Allan RJ (1988) El Niño southern oscillation influences in the Australian region. Prog Phys Geogr 12:313-348

Allan R, Ansell T (2006) A new globally-complete historical gridded mean sea level pressure data set (HadSLP2): 1850-2004. J Clim 19:5816-5842. doi:10.1175/JCLI3937.1

Anderson BT (2003) Tropical Pacific sea-surface temperatures and preceding sea level pressure anomalies in the subtropical North Pacific. J Geophys Res 108:4732. doi:10.1029/2003JD003805

Anderson BT (2004) Investigation of a large-scale mode of oceanatmosphere variability and its relation to tropical Pacific sea surface temperature anomalies. J Clim 17:4089-4098

Anderson BT (2007) Intraseasonal atmospheric variability in the extratropics and its relation to the onset of tropical Pacific sea surface temperature anomalies. J Clim 20:926-936

Anderson BT, Maloney E (2006) Interannual tropical Pacific sea surface temperatures and preceding subtropical North Pacific sea level pressure anomalies in the NCAR CCSM2.0. J Clim 19:998-1012

Ashok K, Guan ZY, Yamagata T (2003) Influence of the Indian Ocean dipole on the Australian winter rainfall. Geophys Res Lett 30(15):1821. doi:10.1029/2003GL017926

Barnett T, Dümenil L, Schlese U, Roeckner E, Latif M (1989) The effect of Eurasian snow cover on regional and global climate variations. J Atmos Sci 46:661-686

BOM (2006) Statement on drought for the 3, 6, and 10-month periods ending 31 October 2006-drought intensifies over eastern and southern Australia as spring rains fail. Drought Statements (National Climate Centre, Bureau of Meteorology), 3 Nov 2006

Bretherton CS, Smith C, Wallance JM (1992) An inter-comparison of methods for finding coupled patterns in climate data. J Clim 5:541-560

Chen S, Chen W, Yu B, Graf HF (2013) Modulation of the seasonal footprinting mechanism by the boreal spring Arctic Oscillation. Geophy Res Lett 40(24):6384-6389

Chen S, Yu B, Chen W (2014) An analysis on the physical process of the influence of AO on ENSO. Clim Dyn 42(3-4):973-989

Cherry S (1996) Singular value decomposition analysis and canonical correlation analysis. J Clim 9:2003-2009. doi:10.1175/1520-0442(1996)009<2003:SVDAAC >2.0.CO;2

Chiew FHS, Piechota TC, Dracup JA, McMahon TA (1998) El Niño/Southern Oscillation and Australian rainfall, streamflow and drought: links and potential for forecasting. J Hydrol 204(1):138-149

Choi K-S, Oh S-B, Byun H-R, Kripalani RH, Kim D-W (2011) Possible linkage between East Asian summer drought and North Pacific Oscillation. Theor Appl Climatol 103(1-2):81-93

Deser C, Phillips AS, Tomas RA, Okumura YM, Alexander MA, Capotondi A, Scott JD, Kwon Y-O, Ohba M (2012) ENSO and Pacific decadal variability in the Community Climate System Model version 4. J Clim 25(8):2622-2651

Feng J, Li JP, Li Y (2010) A monsoon-like southwest Australian circulation and its relation with rainfall in southwest Western Australia. J Clim 23:1334-1353. doi:10.1175/2009JCLI2837.1

Furtado JC, Di Lorenzo E, Anderson BT, Schneider N (2012) Linkages between the North Pacific Oscillation and central tropical Pacific SSTs at low frequencies. Clim Dyn 39(12):2833-2846

Gallant AJE, Hennessy KJ, Risbey J (2007) Trends in rainfall indices for six Australian regions: 1910-2005. Aust Meteorol Mag 56(4):233-239

Gill AE (1980) Some simple solutions for heat-induced tropical circulation. Q J R Meteorol Soc 106:447-462

Gong D, Wang S (1999) Definition of Antarctic Oscillation Index. Geophys Res Lett 26:459-462

Hendon HH, Thompson DWJ, Wheeler MC (2007) Australian rainfall and surface temperature variations associated with the Southern Hemisphere annular mode. J Clim 20:2452-2467. doi:10.1175/JCLI4134.1

Jones DA, Wang W, Fawcett R (2009) High-quality spatial climate data-sets for Australia. Aust Meteorol Ocean J 58(12):233-248. http://www.bom.gov.au/amoj/docs/2009/jones_hres.pdf

Kalnay E et al (1996) The NCEP/NCAR reanalysis project. Bull Am Meteorol Soc 77:437-471. doi:10.1175/1520-0477(1996)077<0437:TNY $\mathrm{RP}>2.0 . \mathrm{CO} ; 2$

Kistler R, Collins W, Saha S, White G, Woollen J, Kalnay E, Chelliah M, Ebisuzaki W, Kanamitsu M, Kousky V, van den Dool H, Jenne R, Fiorino M (2001) The NCEP-NCAR 50-year reanalysis: monthly means CD-ROM and documentation. Bull Am Meteorol Soc 82:247-267

Li X-F, Yu J et al (2013) Recent summer rainfall increase and surface cooling over Northern Australia since the Late 1970s: a response to warming in the Tropical Western Pacific. J Clim 26(18):7221-7239

Lin Z, Li Y (2012) Remote influence of the tropical Atlantic on the variability and trend in North West Australia summer rainfall. J Clim 25(7):2408-2420

Linkin ME, Nigam S (2008) The North Pacific Oscillation-West Pacific teleconnection pattern: mature-phase structure and winter impacts. J Clim 21:1979-1997

Liu S, Yang S et al (2010) Time-frequency characteristics of regional climate over northeast China and their relationships with atmospheric circulation patterns. J Clim 23(18):4956-4972

Lu L, Hedley D (2004) The impact of the 2002-03 drought on the economy and agricultural employment. Economic Roundup Autumn 2004, The Treasury, Australian Government, 25-44. http://www. treasury.gov.au/documents/817/PDF/roundup_autumn_2004.pdf

Marshall GJ (2003) Trends in the southern annular mode from observations and reanalyses. J Clim 16:4134-4143

Matsuno T (1966) Quasi-geostrophic motions in the equatorial area. J Meteorol Soc Jpn 44:25-43

McBride JL, Nicholls N (1983) Seasonal relationships between Australian rainfall and the Southern Oscillation. Mon Weather Rev 111:1998-2004

Nicholls N (2010) Local and remote causes of the southern Australian autumn-winter rainfall decline, 1958-2007. Clim Dyn 34:835-845

Nicholls N, Lavery B, Frederiksen C, Drosdowsky W, Torok S (1996) Recent apparent changes in relationships between the El Niño 
southern oscillation and Australian rainfall and temperature. Geophys Res Lett 23:3357-3360. doi:10.1029/96GL03166

Park J-Y, Yeh S-W, Kug J-S, Yoon J (2013) Favorable connections between seasonal footprinting mechanism and El Niño. Clim Dyn 40(5-6):1169-1181

Raupach MR, PR Briggs, V Haverd, EA King, M Paget, CM Trudinger (2009) Australian Water Availability Project (AWAP): CSIRO Marine and Atmospheric Research Component: Final report for Phase 3. CAWCR technical report no. 013, $67 \mathrm{p}$

Risbey J, Pook M, McIntosh P, Wheeler M, Hendon H (2009) On the remote drivers of rainfall variability in Australia. Mon Weather Rev 137:3233-3253. doi:10.1175/2009MWR2861.1

Rogers JC (1981) The North Pacific Oscillation. J Climatol 1:39-57

Ropelewski CF, Halpert MS (1987) Global and regional scale precipitation patterns associated with the El Niño/Southern Oscillation. Mon Weather Rev 115:1606-1626

Saji NH, Goswami BN, Vinayachandran PN, Yamagata T (1999) Adipole mode in the tropical Indian Ocean. Nature 401:360-363

Smith TM, Reynolds RW, Peterson TC, Lawrimore J (2008) Improvements to NOAA's historical merged land-ocean surface temperature analysis (1880-2006). J Clim 21:2283-2296

Taschetto AS, England MH (2009) El Niño Modoki impacts on Australian rainfall. J Clim 22(11):3167-3174

Thompson DWJ, Wallace JM (2000) Annular modes in the extratropical circulation. Part I: Month-to-month variability. J Clim 13:1000-1016

Ummenhofer CC, Sen Gupta A et al (2011) Indian and Pacific Ocean influences on southeast Australian drought and soil moisture. J Clim 24(5):1313-1336

Vimont DJ, Battisti DS, Hirst AC (2001) Footprinting: a seasonal connection between the tropics and mid-latitudes. Geophys Res Lett 28:3923-3926

Vimont DJ, Battisti DS, Hirst AC (2003a) The seasonal footprinting mechanism in the CSIRO general circulation models. J Clim 16:2653-2667

Vimont DJ, Wallace JM, Battisti DS (2003b) The seasonal footprinting mechanism in the Pacific: implications for ENSO. J Clim $16: 2668-2675$
Vimont DJ, Alexander M, Fontaine A (2009) Midlatitude excitation of tropical variability in the Pacific: the role of thermodynamic coupling and seasonality. J Clim 22:518-534

Walker GT, Bliss EW (1932) World weather. V Mem Roy Meteorol Soc 4:53-84

Wallace JM, Smith C, Bretherton CS (1992) Singular value decomposition of wintertime sea surface temperature and 500-mb height anomalies. J Clim 5:561-576. doi:10.1175/1520-0442(1992)005<0561:SVDOWS >2.0.CO;2

Wang C (2004) ENSO Atlantic climate variability, and the Walker and Hadley circulations. In: Diaz HF, Bradley RS (eds) The Hadley Circulation: Present, Past, and Future. Kluwer Academic Publishers, New York, pp 173-202

Wang G, Hendon HH (2007) Sensitivity of Australian rainfall to inter-El Niño variations. J Clim 20(16):4211-4226

Weisberg RH, Wang C (1997) A Western Pacific Oscillator Paradigm for the El Niño-Southern Oscillation. Geophys Res Lett 24:779782. doi:10.1029/97GL00689

Wu ZW, Li JP, Wang B, Liu X (2009) Can the Southern Hemisphere annular mode affect China winter monsoon? J Geophys Res 114:D11107. doi:10.1029/2008JD011501

Wu ZW, Dou J, Lin H (2015) Potential influence of the NovemberDecember Southern Hemisphere annular mode on the East Asian winter precipitation: a new mechanism. Clim Dyn 44:1215-1226

Xie SP, Philander SGH (1994) A coupled ocean-atmosphere model of relevance to the ITCZ in the eastern Pacific. Tellus Ser A Dyn Meteorol Oceanol 46(4):340-350

Zhang L, Chang P, Ji L (2009) Linking the Pacific meridional mode to ENSO: coupled model analysis. J Clim 22:3488-3505

Zheng Q, Hu J, Shen B, Gong Z, Feng G (2012) The relationship between North Pacific Oscillation and Summer Floods/ Drougts over North China. Inf Eng Appl 1673-1678. doi:10.1007/978-1-4471-2386-6_228 